\title{
Leafy spurge in Saskatchewan ${ }^{1}$
}

\author{
G. W. SELLECK, R. T. COUPLAND, and C. FRANKTON \\ Selleck, Monsanto Chemical Company, St. Louis, Missouri. Coupland and Frankton, Plant Research Institute, Canada \\ Department of Agriculture, Ottawa.
}

\section{Introduction}

The present interest in the study of leafy spurge (Euphorbia esula L.) has been prompted by the steady advance of this weed since its discovery in North America in 1827. The weed was not recognized in western Canada until the early part of the 20th century. Although the rate of spread has not been rapid, the methods of control used have been relatively ineffective, with the result that large areas of land have become infested. This has convinced many agriculturalists that, if unchecked, it will become a major problem in western Canadian agriculture. Difficulty in control has been enhanced by lack of knowledge concerning relation to habitat and the developmental life history of leafy spurge under western Canadian conditions.

The need for detailed studies of this persistent weed was realized from the findings of the Saskatchewan Weed Survey, which was conducted during 1949-1955 concurrently with the early phases of the studies reported here. More than 9,800 acres were found to be infested in $1 / 3$ of the settled portion of the province covered by the survey. The threat from this and other persistent perennial weeds in Saskatchewan has influenced the provincial government to provide financial assistance to rural municipalities which use approved methods in their control programs.

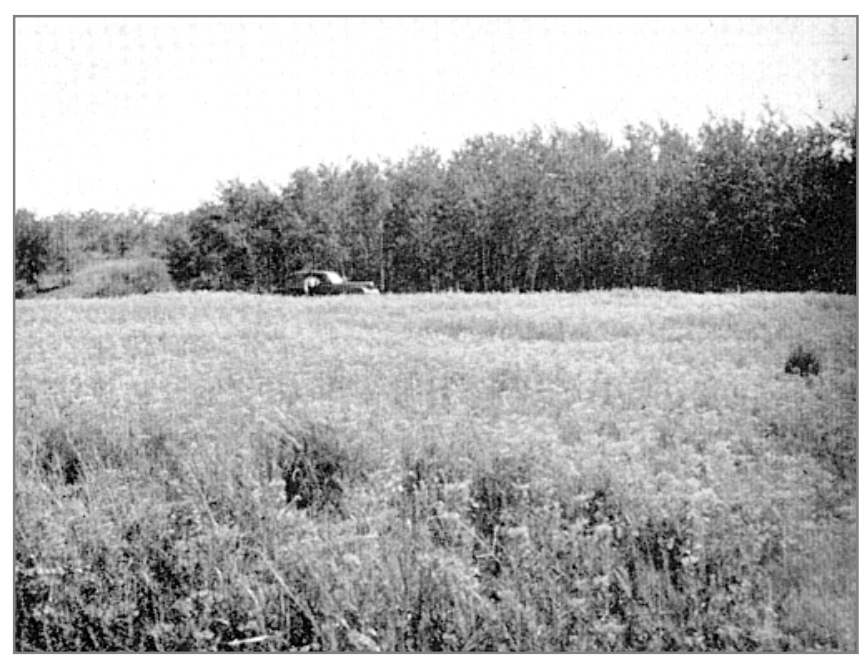

Fig. 1. Leafy spurge growing in competition with brome grass at Site No. 1 (July 10, 1949).

\footnotetext{
${ }^{1}$ Contribution No. 281 of the Department of Plant Ecology, University of Saskatchewan.
} 
The present study is an attempt to relate various aspects of the life history of leafy spurge to factors of the habitat after the pattern suggested for herbaceous plants by Stevens and Rock (1952). Study sites were invariably in locations where infestations occurred as a result of natural migration. These were distributed within an area 300 miles long, and 200 miles wide in various habitats of southern Saskatchewan. Data obtained at these study sites were supplemented by observations which were made during the Weed Survey. This paper deals with 10 years of investigations which began in 1949 .

\section{Literature review}

Species of the genus Euphorbia have long been familiar to man, being considered of medicinal value 2,500 years ago (White et al. 1941). Historically, E. esula has frequently been recognized, for instance, in Linné's "Species Plantarum" (1753) and in "Synopsis Plantarum in Flora Gallica" (De Lamarck and De Candolle 1806). This species has continued to appear in European literature, from a taxonomic point of view (Engler and Prantl 1897) and with respect to distribution and ecology (Hegi c 1906).

The latex has been used medicinally. A poisonous, gummy substance called "euphorbon" was once produced from it. Taken internally, spurges are irritant, emetic and purgative. In cattle it causes scours and weakness, often resulting in death (Muenscher 1940).

Since the species became common to North America, it has received considerable attention of a morphological, physiological and ecological nature. Germination studies were conducted by Hanson and Rudd (1933), Bakke (1936), Brown and Porter (1942), and Bellue (1946). Studies by Murley (1945) and Landes (1946) contributed to morphology of the seed. Seedlings were described by Hanson and Rudd (1933), Helgeson and Hanson (1938), and by Pavlychenko and Harrington (1938). The depth of penetration and lateral development of the root system, as well as the development of plants from root cuttings, have been described in most detail by Hanson and Rudd (1933) and by Pavlychenko and Harrington (1938). Bakke (1936) described the occurrence of reproductive buds on the roots. Gaucher (1902), Bakke (1936) and Pavlychenko and Harrington (1938) conducted studies on the morphology of the plant. Physiological root relations have been discussed primarily by Arny (1932) and Bakke (1936). Although several authors have described the method of seed dispersal, Bakke (1936) is the only one who discussed in detail the morphological and physiological processes involved. The main contributors to information on rate of spread of the species were Batho (1932), Bakke (1936), Pavlychenko and Harrington (1938) and Bellue and Berry (1941).

\section{Taxonomy and nomenclature}

Euphorbia esula is a perennial dictoyledonous herbaceous plant of the family Euphorbiaceae. The dense habit of growth and yellowish-green inflorescence are its most noticeable characteristics. Latex is present in the entire plant in all stages from early emergence until late maturity.

The stems are tough and woody, being 8 to 36 inches high, often branching below the soil surface to produce erect clumps. Stems are pale green in summer, but become red in

Page 2 of 45 
the fall. The degree of branching of stems is variable. Sometimes the dead stems persist into the next growing season. The leaves are 0.25 to 2 inches long and 0.16 to 0.5 inch wide, lanceolate, subsessile, alternate, entire, bluish-green in color and weakly veined with the exception of the midrib. A whorl of wider, shorter leaves subtends the terminal many-rayed forking flower cluster. Sticky, milky latex is exuded at points of injury.

The yellowish-green, flower-like clusters are borne on lateral branches or terminal umbels. Each pedicel of the umbel bears a cyathium (producing both staminate and pistillate flowers) from which 2 opposite branches arise. Each of these in turn produces a cyathium, and the process is repeated until the single, original floral branch has divided into 8 to 16 branchlets.

The cyathium is yellowish-green and resembles a calyx with united lobes. This structure (2.5-3 mm high) bears 4, two-horned nectar-secreting glands. The involucre, which is situated within the cyathium, contains the flower cluster. The glands alternate with the involucral lobes, with 1 gland absent or modified, providing a space for the arching gynophore. The flower cluster is comprised of 15 to 20 stalked, staminate flowers, each consisting of a single stamen, and a single-stalked pistillate flower. The whole cyathium is enclosed by 2 involucral yellowish-green bracts 1 to $1.3 \mathrm{~cm}$ long. The inflorescenece becomes more yellow with maturity, and is borne long enough to give the plant an almost unchanged appearance for some months.

The roots are perennial, woody and tough, with numerous, spreading rhizomes near the surface. Pink-colored buds, which give rise to dew shoots, are numerous on roots and rhizomes.

The fruit develops from a superior, 3-celled ovary which has central placentation. The seeds are 2 to $2.5 \mathrm{~mm}$ in length by $1 \mathrm{~mm}$ in width, oval in outline, almost circular in cross-section, sometimes oblong or broadly wedge-shaped, with a prominent disc-like caruncle at the narrow end. The seed coat is faintly reticulated, chalky grey to various shades of yellow and brown, frequently with reddish spots. A brown raphe extends from base to apex, terminating at the prominent yellow tubercle, the caruncle (Murley 1945). The seeds can be separated from those of other species by their shape, size, color, surface topography and the type of caruncle (Bellue and Berry 1941, Murley 1945, Bellue 1946).

Considerable confusion and disagreement has arisen concerning the taxonomic classification of Euphorbia because of hybridization within the genus. Consequently, there has been some question whether the aggressive perennial which has become firmly established in North America is E. esula or E. virgata or some other species or variety of the same affinity. Moore (1958) concludes that all North American collections, including those in the present study, represent E. esula.

\section{Geographical distribution}

Bentham and Hooker (1883) and Pax (1897) (as reported by Engler and Prantl 1897) report distribution of the genus Euphorbia to be world wide (except for Australia). E. esula extends across northern (Drude 1896) and southern Europe (Hegi c 1906), with its centre of distribution in the Caucasus (Croizat 1945).

Page 3 of 45 
Bakke (1936) states that E. esula was found first in North America at Newberry, Massachusetts, in 1827. Since then, it has been found in 20 states from the Atlantic to the Pacific (Bakke 1936, Barnett and Hanson 1934, Batho 1931, Bellue 1946, Fix 1946, Hanson 1933, Litzenburger et al. 1945, Maguire 1941, Murley 1945, Norton 1899, Warren and Freed 1953). With the exception of Newfoundland, it has been reported from every province in Canada (Groh and Frankton 1949, Lindsay 1950). Lindsay (1950) estimates the Canadian infestations at 20,000 to 25,000 acres. This estimate is conservative, since he considers only about 10,000 acres to be infested in western Canada, which is the approximate amount mapped in Saskatchewan alone. It is likely that the infested acreage in Canada approaches 35,000 to 40,000 acres.

Leafy spurge is present in several locations in southern Manitoba (Groh 1944), infesting some 8,000 acres (Craig 1953), and has become so well established in some areas that good farms have been abandoned (Experimental Farm News 1938). The weed is present in the Pence River area of Alberta and adjacent portions of British Columbia (Groh and Frankton 1949, Putnam, ${ }^{2}$ personal communication 1958). The main distribution in Alberta lies from Athabaska south to the United States border (Sterling 1956), with 250 farms infested in 32 Rural Municipalities (Lobay, ${ }^{3}$ personal communication 1958).

Although E. esula is widely distributed in Eurasia, the weed is not considered to be particularly noxious there. This may be due to the type of agriculture which is practiced, the combination of weather conditions, or competing species and natural predators which may keep the weed in check. Clapham et al. (1952) describe it in the British floral but do not make any reference to the plant being particularly troublesome. Blackman ${ }^{4}$ (1954) states that the weed is of no consequence in Britain and that references are not available which would suggest that the species is of agricultural importance in Europe. The Minister of Lands and Forests of West Germany ${ }^{5}$ (1955) states that E. esula as a field weed is as yet of no consequence.

In North America, on the other hand, E. esula is a vigorous and strongly competitive plant, reproducing actively both from seed and from rhizomes. It has the ability to tolerate a variety of habitats and to survive under most unfavorable conditions. Clute (1937) states that, once established, the weed is practically impossible to eradicate. Bakke (1936) reports that it has become a serious menace to agriculture in Iowa, Minnesota and the Dakotas. Certainly Manitoba may be included in this category (Batho 1931) as well as Saskatchewan.

There is a marked similarity in the kinds of environments in which the species has been found in Europe, Asia and North America. Hegi (c 1906) reports that the weed flourishes in dry meadows, associated with grass species, and makes several references to the weed being present in deposits of sand. Von Kirchner and Loew (1930) concur with this observation, but add that the species is also abundant in bushes and edges of woods, and, to a lesser extent is found along railway embankments. It has a preference for sandy-

\footnotetext{
${ }^{2}$ N.F. Putnam, Field Crops Commissioner, B.C. Dept. of Agric., Victoria, B.C.

${ }^{3}$ W. Lobay, Supervisor, Soils and Weed Control, Field Crops Branch, Alta. Dept. of Agric., Edmonton, Alta.

${ }^{4}$ G.E. Blackman, Dept. of Agric., Oxford Univ., England, personal communication.

${ }^{5}$ J. Oibir, Minister of Lands and Forests, Bonn 12, West Germany.
}

Page 4 of 45 
loam soil. Cosson and Saint-Pierre (1861) list similar habitats for leafy spurge in France, including stony hillsides and rocky forest lands. Sendtner (1860) mentions it as being common on mountainsides along the Danube River and Heimans et al. (1948) report the weed as being present along roads and riverbanks in middle Europe, Sweden, and western Asia. The literature indicates that E. virgata and E. cyparissias are adapted to similar habitats.

In North America, Bellue (1946) reports that E. esula infests pastures, grain fields, ditches, waste places and wooded areas. The present authors have observed numerous infestations of the weed along roadsides in North and South Dakota, and Wisconsin. In Wisconsin the species often flourishes in open-grown oak woods, while in Saskatchewan it has been found in almost every terrestrial habitat, with the exception of coniferous forest. Infestations are most common in abandoned or disturbed lands, cultivated fields, and in overgrazed pastures. It has even been found to spread in native ungrazed grassland (Stipa-Agropyron), presumably after establishment from seed in a gopher mound. The species becomes established quite readily in competition with shrubs, and in open stands of aspen groves. It is present in a variety of topographic positions, from tile flat beds of glacial lakes to the slopes of sand dunes and glacial moraines. It also thrives in various soil conditions and, in Saskatchewan, is present in the brown, dark brown, black and grey soil zones. The weed flourishes even in such unfavorable situations as eroded slopes and saline depressions. Bathe (1932) has commented on its ability to grow equally well in fine- and course-textured soil in Manitoba.

Other species of the genus Euphorbia are weedy in North America. Murley (1945) reports E. maculata, E. supina (upright and prostrate spotted spurge), E. cyparissias (cypress spurge) and E. marginata (snow-on-the-mountain) as potentially dangerous weeds in Iowa. In Canada, E. cyparissias is rare in the west, but widely distributed in the east (Lindsay 1950), while a broader-leaved species, E. lucida, found in Alberta is considered to be another serious perennial weed (Groh 1935). A few infestations of E. cyparissias and one of E. lucida have also been found in Saskatchewan.

\section{Description of the area}

The study sites are primarily representative of the mixed prairie and aspen grove regions of Saskatchewan (Coupland 1950, Coupland and Brayshaw 1953), but some of the work was done within the boreal forest zone. The surface geological deposits and soil parent materials are all of glacial origin from extensive invasions of the Keewatin ice sheet which has vacated the area within the last 10,000 to 12,000 years (Kupsch 1960), leaving a thick mantle of glacial drift which has been modified in many areas by melt waters from the glacier. The soils are brown to black in colour, mildly alkaline in reaction, and are developed on lacustrine deposits of sandy to clay texture as well as on glacial till which has been modified to varying degrees. Some of the sandy areas have been modified by wind (Mitchell and Moss 1948).

The climate of the area is characterized by great extremes in temperature between summer and winter and by comparatively low precipitation. Extremes in temperature above $100^{\circ} \mathrm{F}$ and below $-50^{\circ} \mathrm{F}$ have been recorded. Wide variations in temperature be-

Page 5 of 45 
tween day and night and from day to day are frequent in all seasons. The mean annual precipitation is below 18 inches at all meteorological stations, but has varied between 7 and 25 inches in different years at the same station. Most of the winter precipitation from November to March is in the form of snow. The ground remains frozen for a period of from 4 to 5 months. The growing season is relatively short (with a mean of 106 frost-free days), warm to hot, with bright, sunny weather prevailing. Usually about one-half of the total annual precipitation falls from April to July, inclusive. The prevailing winds are westerly, the colder northwesterly winds being most typical (Kendrew and Currie 1955).

\section{Procedure}

The aspects of life history and ecological adaptation of leafy spurge reported upon in this paper were investigated in sites representative of infestations in various soil types in the brown, dark brown and black soil zones. The infestations were selected as ones in which the weed had invaded extensively. At each location studies were made in all habitats in which it occurred (Table 1). None of the infestations was a result of introduction or manipulation by the investigators. The only modification which was made was to fence a part or parts of each of the study sites for the purpose of removing the influence of domesticated livestock and attempts at control by the farmer. Each fence enclosed a patch of the weed with an uninfested border for perimeter expansion. The fence posts were placed at 5-m intervals and were used as points of reference for a grid comprised of plots 5 miles square. Smaller plots (usually $1 \mathrm{sq} \mathrm{m}$ in size) were permanently located with reference to this grid. Measurements outside of exclosures were frequently along line transects, the ends of which were permanently marked, but some plots were used as well. The response of the species to various factors was studied in these sites from 1951 to 1958.

Table 1. The location and habitat characteristics of study sites.

\begin{tabular}{|c|c|c|c|c|c|c|c|}
\hline Site no. & $\begin{array}{l}\text { Legal } \\
\text { description } \\
\text { of land }\end{array}$ & $\begin{array}{c}\text { Direction and } \\
\text { distance from } \\
\text { Saskatoon } \\
\text { (mi) }\end{array}$ & Soil zone ${ }^{1}$ & Texture & $\begin{array}{c}\text { Geological } \\
\text { origin }\end{array}$ & Topography & Land use \\
\hline (patches 1-6) & & N.W. 80 & Black & $\begin{array}{l}\text { Fine sandy } \\
\text { loam }\end{array}$ & Alluvial & $\begin{array}{c}\text { Moderately } \\
\text { undulating }\end{array}$ & Native grassland \\
\hline $\begin{array}{l}2(1) \ldots \ldots \\
2(2) \ldots \ldots\end{array}$ & $\begin{array}{l}\text { N.W. 32-44-1 W3 } \\
\text { N.W. 32-44-1 W3 }\end{array}$ & N.E. 60 & Black & Sand & Dune & Sand dune & $\begin{array}{l}\text { Native grassland } \\
\text { Abandoned, natu- }\end{array}$ \\
\hline $3(1)$ & S.W. 3-18-2 W3 & S. 122 & Brown & Sandy loam & Glacial out- & Gently & Recently abandon- \\
\hline $3(2)$ & “ & “ & “ & “ & wasn & rolling & $\begin{array}{l}\text { ed } \\
\text { Abandoned, reseed- }\end{array}$ \\
\hline $3(3)$ & “ & “ & “ & “ & “ & “ & $\begin{array}{l}\text { wheat grass } \\
\text { Native grassland }\end{array}$ \\
\hline & N.E. $22-17-19$ W2 & S.E. 148 & Dark brown & Clay & Lacustrine & Gently & Abandoned, reseed- \\
\hline & N.W. 14-19-33 W1 & S.E. 240 & Black & Loam & Glacial till & Gently & Recently abandon- \\
\hline & S.W. $34-35-6$ W3 & S.W. 12 & Dark brown & Sandy loam & Dune & Sand dune & $\begin{array}{l}\text { ed (annual weeds) } \\
\text { Abandoned, natu- } \\
\text { rally reorassed }\end{array}$ \\
\hline 7. & S.E. $4-43 a-3$ W3 & N.E. 36 & Black & $\begin{array}{l}\text { Silty clay } \\
\text { loam }\end{array}$ & Lacustrine & $\begin{array}{c}\text { Moderately } \\
\text { undulating }\end{array}$ & $\begin{array}{l}\text { Native pasture, } \\
\text { then cultivated }\end{array}$ \\
\hline
\end{tabular}

${ }^{1}$ Soil zones according to Mitchell et al. (1944). 
Choice of the study sites was made after experience had been gained in a survey of distribution and adaptation of the weed in various parts of Saskatchewan for 2 years. The data obtained from $1 / 3$ of the settled part of the province during this survey (which continued until 1955) was of considerable use in supplementing the observations made in the study areas.

Experimentation was utilized as a necessary means of obtaining data under conditions which were different from those already available and under controlled environments. Consequently, laboratory and greenhouse studies were employed to obtain further information concerning several phases of the investigation. Some experimentation was conducted also in the field study sites or on the University experimental area, where an infestation was established for the purpose. Information concerning germination, development, and vigour of underground parts was obtained in this way to supplement that provided by studies of natural infestations.

\section{Distribution in Saskatchewan}

To investigate the distribution of leafy spurge in Saskatchewan in relation to climate, soils, and agricultural practices, a farm-to-farm survey was conducted during 1949 to 1955, as part of the Saskatchewan Weed Survey which included 4 other persistent weeds. In this survey an attempt was made to locate every infestation of leafy spurge within 117 rural municipalities and local improvement districts (each approximating 324 sq miles in extent). The area traversed involved about 1/3 of the settled area of Saskatchewan, and an estimated 10,000 farms were visited.

Information obtained from Agricultural Representatives and municipal officials (when available) was used in finding the first infestation. A careful survey was then made of adjacent farms, to which the weed had frequently spread. Where no reports of the weed were available, a farm-to-farm survey was frequently conducted to discover whether the lack of reports was due to lack of knowledge concerning the identity of the species. Frequently new infestations were found in this way. Usually about $40 \%$ of the farmers were contacted in each municipality.

Estimates of the acreage infested by the weed were made on the basis of the area that would be involved in an attempt to eradicate each infestation by tillage. Small, isolated patches were each considered to infest 1 acre. This provided for an area encompassed by a circle with a radius of approximately 120 feet about the centre of the patch. Patches were considered to be isolated if the distance from the edge of one to that of the nearest was greater than 150 feet. Individual patches larger than 60 feet in diameter were each considered to occupy more than 1 acre, an allowance being made for a noninfested zone 90 feet in width around each patch to permit the turning of tillage implements. In no instance was the total acreage or part of a field considered to be infested unless patches were scattered more or less throughout at a density of at least 1 patch for every 4 acres.

By use of the above criteria, 9,828 acres of leafy spurge were mapped in 945 quarter sections in 87 of the 117 municipalities surveyed. The majority of the most seriously infested areas occur in the southeastern part of the province. Thirty percent of the infested area occurred in 3 municipalities, in each of which 500 acres or more were considered to 
be infested. Infestations in 22 other municipalities, each containing between 100 and 500 infested acres, comprised $51 \%$ of the infested acreage. The remaining infested area (19\%) occurred in 62 municipalities. The weed was not found in 30 of the municipalities. In $41 \%$ of the infested quarters, the infested area was limited to 1 acre or less (frequently to 1 patch). However, in $11 \%$ of them the species had spread to exceed 20 acres in area.

Since the estimate of area infested provided no information concerning the density of the stand, an estimate was made of the percentage of the soil surface occupied by patches of the weed in each infestation. The proportion of the infested acreage which was actually occupied by patches of the weed was $1 \%$ or less in $359(38 \%)$ of the infested quarter sections, but exceeded $20 \%$ in 141 (14\%) of them.

Notes were taken concerning the agricultural use to which the land was being put, and with respect to the competing species. Fifty-six percent of the infested acreage was under cultivation, while $23 \%$ had been abandoned from cultivation (frequently because of the presence of leafy spurge). Twenty-one percent of the infested acreage occurred in land which had never been cultivated. The weed occupied cultivated land in $50 \%$ of the infested quarters and in native grassland in $39 \%$ of them. The average extent (per quarter) of the infestation in cultivated land (11.5 acres) was much higher than under any other land uses. The average weighted percentage of the soil surface occupied within infestations under each land use was also calculated (Table 2).

The relatively mesophytic character of the weed is indicated by the occurrence in the brown soil zone of only $4.1 \%$ of the infested quarters and $9.8 \%$ of the infested acreage, while approximately $60 \%$ of the infestation occurred in the black soil zone. During the survey it seemed that leafy spurge grew most commonly in soils of coarse texture. To measure the degree of association with various soil textures, the infestations were classified into 3 groups-those occurring on sand to light loam, loam to clay loam, and clay to heavy clay. Infestations on azonal soils were not considered. The numbers of infested quarter sections and infested acres were calculated for each of these 3 textural groups and compared with the total number of quarters and acres in each township. Forty-eight percent of the infested quarters were in the coarse-textured group, $42 \%$ were in the intermediate group, while $10 \%$ were in clay soils. Fifty-one percent of the infested acreage occurred in the loam to clay-loam textures. The mean size of patch was 8.6 acres in the coarsest textural group, 12.7 in the medium group and 11.3 in the finest textured soils. When these figures are compared with the proportion of each textural group available for infestation in each township, it is revealed that the highest percentage of infested quarters was in the coarsest soil textural class $(3.76 \%)$. The percentage of infested acres showed a similar trend, with the weed infesting

Table 2. Distribution of leafy spurge according to land use. (Saskatchewan Weed Survey of 117 rural municipalities, 1949-1955.)

\begin{tabular}{|c|c|c|c|c|}
\hline Land use & $\begin{array}{c}\text { Acres } \\
\text { infested }\end{array}$ & $\begin{array}{l}\text { Quarters } \\
\text { infested }\end{array}$ & $\begin{array}{c}\text { Mean } \\
\text { infestation } \\
\text { per quarter } \\
\text { (acres) }\end{array}$ & $\begin{array}{c}\text { Mean } \% \\
\text { of soil } \\
\text { surface } \\
\text { occupied } 1\end{array}$ \\
\hline Cultivated. & 5,459 & 475 & 11.5 & 8.8 \\
\hline Abandoned from cultivation & & & & \\
\hline Annual weeds.......... & 133 & 24 & 5.5 & 27.4 \\
\hline Perennial weeds ....... & 391 & 82 & 4.8 & 34.4 \\
\hline Naturally regrassed..... & 770 & 110 & 7.0 & 26.5 \\
\hline Reseeded to grass..... & 990 & 112 & 8.8 & 22.3 \\
\hline Native sod (never tilled). & & & & \\
\hline Grassland (pastures, ete.) & 1,186 & 373 & 3.2 & 22.3 \\
\hline Meadow............... & 83 & 38 & 2.2 & 16.8 \\
\hline Woodland............ & 536 & 87 & 6.2 & 12.4 \\
\hline Shrub.............. & 214 & 130 & 1.6 & 13.5 \\
\hline Garden, lawn, shelterbelt... & 66 & 45 & 1.5 & 7.3 \\
\hline Total.. & 9,828 & $945^{2}$ & - & - \\
\hline
\end{tabular}

1 Within infested acreage.

2 Some quarters had infestations in two or more land classes.

Page 8 of 45 
$0.21 \%$ of the sandy soil group and $0.16 \%$ of the clayey soils (Table 3 ).

The relation between soil texture and extent of infestation within infested quarters was also considered (Table 4). With the smallest infestations (up to 5 acres), the size of the infestation generally increased as the texture graded from clay to sand. This trend occurred also with the percentage of quarter sections and the percentage of acres which were infested for all sizes of infestations. These data, therefore, support observations which were made during the survey with respect to the greater adaptability of the weed to sandy areas.

\section{Recent migrations}

To ascertain the rapidity of invasion of this species over extensive areas, resurveys were made in 3 municipalities. In one of these, the number of quarters infested was found to have increased from 67 to 123 , and the acres infested from 342 to 820 , during the period 1950 to 1953 . This increase occurred in spite of an active control campaign in which the weed was eradicated from 11 quarter sections. Similar increases were observed in the other 2 municipalities.

It is therefore evident that leafy spurge has increased rapidly in Saskatchewan and now constitutes a serious threat to agriculture. Its abundance is particularly noteworthy when it is considered that the first collection known in Saskatchewan was made in 1927. However, information obtained locally about the infestations indicates that some of them were present in Saskatchewan as early as 1900. The frequent occurrence of leafy spurge along the route of the "Carlton Trail" and on the sites of early settlements also suggests that introduction was at an early date. For example, the infestation at Site No. 1 is located near the headquarters of the legislative buildings from which the North-West Territories were governed until 1905. Infestations at Site No. 5 and in the vicinity of Site No. 2 are situated on the Carlton Trail. It is probable that seeds of leafy spurge were present in horse feed carried by settlers or by the North-West Mounted Police.

Importations of contaminated seed and forages have often been suggested as the source of more recently introduced infestations. The infestation at Site No. 2 was reported to have originated from contaminated seed oats and at Site No. 4 from contami- 
nated brome grass seed. There were several reports during the survey of infestations having originated after forage had been shipped in during the drought of the 1930's. The presence of several infestations adjacent to railway rights-of-way suggests that railways have also contributed to distribution of the seed. Contamination of cultivated fields often resulted from spreading of vegetative parts by tillage implements and of seed by careless harvesting and threshing practices. The weed has frequently spread from farm to farm along roadsides when dragged by road machinery.

Certainly natural agencies have been important in the distribution of the weed in Saskatchewan. Infestations often follow the contours of shallow basins which drain away surface water. Domestic and wild animals have been credited with the transport of seed and even of vegetative parts. In one instance, patches of the weed developed where the entrails of a deer had been dragged about.

\section{Developmental history}

Certain aspects of the developmental history of a weed are of significance in its successful naturalization and the subsequent vigour and persistence which it displays.

\section{Germination}

Seed dormancy of leafy spurge permits germination for a period up to 5 years following maturity. To study viability under as natural conditions as possible, recently matured seeds were placed in bottomless germination flats ( $18 \times 12 \times 3$ inches) in the experimental field at Saskatoon. Of 6,400 seeds which were harvested from various sites and planted in 1951, 14.5\% germinated within the first 12 months. Another $6 \%$ germinated in 1953, but subsequent germination in 1954, 1955 and 1956 totalled less than 1\%. Only 3 seeds germinated in 1956, while none germinated in 1957. In another field experiment, where seed from Site No. 1 only was used, longevity did not exceed 3 years. Germination was $28.8 \%$ (of 10,600 seeds) in the first year, less than $1 \%$ during the second, and was limited to only 2 .seeds in the third year.

Bakke (1936) reports that (in Iowa) seeds germinate throughout the entire growing season, if moisture is adequate. Early spring, however, is the most favorable period for germination. In the first Saskatchewan experiment referred to above, $13.6 \%$ of the germination occurred in April and 82.1\% in May, with occasional germination until October 15. In the second experiment (which was started in the fall of 1954) $23.0 \%$ of the seedlings appeared during the following May, 75.6\% in the first 10 days of Jan., and $1.4 \%$ between June 10 and October 10. The earlier germination in 1952 was apparently associated with an earlier occurrence of warmer temperatures. Maximum emergence took place after 10 days with a maximum air temperature of $70^{\circ} \mathrm{F}$ or higher in late April. During 1955 similar temperatures were not reached until the last week in May, accounting for maximum germination in early June.

Page 10 of 45 


\section{Influence of soil texture and seed source}

In the above experiments, germination in silty clay loam soil at Saskatoon was compared with that in soil transported from sites where the seed was collected, care being taken to select the soil from uninfested portions of the site. Seed and soil were collected in this way representing heavy clay, loam, sandy loam and sand textures. Duplicate, randomized samples of 200 seeds each were sown in soil of each texture. In all instances seeds were planted during the same autumn that they were harvested. In addition, 1 -year-old seeds were used from 1 site (No. 1). Seed germinated more completely in the soil from sites in which it was collected than in Saskatoon soil (Table 5), the trend being significant beyond the $1 \%$ level. These soils were (with 1 exception) coarser in texture than Saskatoon soil.

To remove the possible effect of adaptation to soil type, duplicate samples of 200 seeds each from 1 seed source were planted in a variety of soils in flats at Saskatoon in the fall of 1954. In this instance the percentage germination increased with increasing fineness of soil texture (Table 6). These conflicting data with respect to the effect of soil texture in this and the previous experiment suggests either: (1) that adaptation to soil type may be sufficient to mask the effect of texture or (2) that germination was influenced more by other factors, such as temperature or moisture, which may vary sufficiently to promote germination in fine-textured soil at one time and in coarse soil another.

The germination of individual samples of seed collected from various sites during the first year following maturity varied from less than $1 \%$ to $44 \%$ (Table 5 ). This indicates the existence of a dormancy period in seed samples from some locations and/or relatively low viability of the seed. To clarify this point, seed was collected from 4 locations and germinated under uniform conditions in the laboratory. Considerable variation occurred in the percentage germination of seed from different sources, ranging between 4.2 and $38.0 \%$. No significant difference in germination occurred between seed samples which
Table 5. Percentage germination of seed of sown in soil from the same site in comparison with Saskatoon soil. The seed was sown under field conditions in the fall of 1951. Germination is determined for each year on the basis of the number of seeds remaining after germination the previous year.

\begin{tabular}{|c|c|c|c|c|c|c|c|}
\hline \multirow{2}{*}{$\begin{array}{l}\text { Seed source } \\
\text { (Site) }\end{array}$} & \multirow{2}{*}{$\begin{array}{l}\text { Soil association and } \\
\text { texture }\end{array}$} & \multicolumn{3}{|c|}{$\begin{array}{c}\text { SoIL CoRRESPONDING } \\
\text { TO SEED SOURCE }\end{array}$} & \multicolumn{3}{|c|}{$\begin{array}{l}\text { SAsKatoon SorL (El- } \\
\text { stow silty clay loam) }\end{array}$} \\
\hline & & 1952 & 1953 & 1954 & 1952 & 1953 & 1954 \\
\hline No. $4 .$. & Regina heavy clay & 0.8 & 2.7 & 3.6 & 7.7 & 4.5 & 0.5 \\
\hline No. 5 .. & Oxbow loam & 42.0 & 3.7 & 0 & 7.2 & 2.4 & 0 \\
\hline No. $10 \ldots$ & $\begin{array}{l}\text { Weyburn loam } \\
\text { Meota fine sandy }\end{array}$ & 3.2 & 1.3 & 3.1 & 4.5 & 0.8 & 0 \\
\hline No. $7 \ldots .$. & loam & 5.0 & 20.0 & 0 & 0.3 & 11.8 & 0 \\
\hline No. $1(1950)$ & Dune sand & 44.2 & 2.2 & 17.9 & 19.7 & 3.4 & 0 \\
\hline No. 1 (1951) & Dune sand & 26.5 & 6.8 & 0 & 18.5 & 3.7 & 0 \\
\hline No. 3 (west) & Chaplin sandy loam & 9.5 & 14.6 & 0 & 4.7 & 3.4 & 0 \\
\hline No. 3 (east). & Chaplin sandy loam & 24.8 & 7.4 & 0 & 14.3 & 6.4 & 0 \\
\hline
\end{tabular}

Table 6. Percentage germination of leafy spurge seed collected at Site No. 1 and seeded outdoors in various soil textures at Saskatoon in the fall of 1954. Data for recently-harvested and 1-year-old seed are compared.

\begin{tabular}{|c|c|c|c|c|}
\hline \multirow{3}{*}{ Depth (in.) } & \multicolumn{4}{|c|}{ Year Germinated } \\
\hline & \multicolumn{2}{|c|}{ Seed 1-yr old } & \multicolumn{2}{|c|}{ Seed recently harvested } \\
\hline & 1952 & 1953 & 1952 & 1953 \\
\hline $\begin{array}{l}\text { Surface..... } \\
0.25 \ldots \ldots \\
0.5 \ldots \ldots \\
1.0 \ldots \ldots \\
2.0 \ldots \ldots \\
3.0 \ldots \ldots \\
4.0 \ldots \ldots \\
5.0 \ldots \ldots \\
6.0 \ldots \ldots \\
\end{array}$ & $\begin{array}{r}2.0 \\
11.5 \\
64.0 \\
45.0 \\
57.0 \\
38.0 \\
12.5 \\
1.2 \\
0.2\end{array}$ & $\begin{array}{l}4.6 \\
2.3 \\
1.4 \\
6.3 \\
0.0 \\
0.8 \\
- \\
-\end{array}$ & $\begin{array}{r}1.5 \\
22.0 \\
24.5 \\
22.5 \\
39.5 \\
22.5 \\
- \\
-\end{array}$ & $\begin{array}{r}4.1 \\
4.5 \\
10.6 \\
5.0 \\
14.9 \\
7.7 \\
- \\
-\end{array}$ \\
\hline
\end{tabular}
leafy spurge harvested from various sites and 
were collected from 2 different patches at the same site (No. 8), but the mean differences which occurred between seed collected from different sites were significant beyond the $2 \%$ level. These results may indicate genetic differences or differences in dormancy characteristics. The available evidence favours the former explanation, since percentage germination of seed collected in different years in the same site is similar. For example, in several experiments which were conducted over a period of 3 years, seed from Site No. 8 never germinated more than 7 or $8 \%$, and germination of seed from Site No. 2 was always lower (approximately 20\%) than that from Site No. 3 (approximately 30\%). Seed from Site No. 1 consistently germinated well (between 60 and 85\%).

\section{Depth of seeding}

The ability of seed to emerge from a variety of depths in the soil was demonstrated during the course of this study. Seed of high germinability was collected (from Site No. 1) in 1950 and 1951 and sown at various depths in the fall of 1951 (Table 7). That dormancy is a factor in newly-harvested seed is shown by the fact that germination of seed 1-year old exceeded that of newly-harvested seed at nearly every soil depth. The trend was reversed in the second year after seeding. Maximum emergence occurred from depths of 0.5 to 2 inches but germination occurred at depths ranging from the surface to 4 inches Above 0.5 inch moisture may have been too low and temperature too high for germination, while below 2 inches the temperature of the soil may have been below optimum or food reserves in the endosperm insufficient. The ability to produce seedlings from such a wide range of depths reflects the capacity for re-establishment of the weed by seedlings where plants have been eliminated.

\section{Age of seed}

Laboratory investigations with limited supplies of seed of various ages and from various sources (Table 8) supported the results of the above field test (Table 7) and of other laboratory tests (Table 9) as seed 1-year-old

Table 7. Percentage emergence of leafy spurge seed over a 2-year period. The seed was sown under field conditions at various depths at Saskatoon in silty clay duplicate samples of 200 seeds newly-harvested and 1-year old from Site No. 1.

\begin{tabular}{|c|c|c|c|c|}
\hline \multirow{3}{*}{ Depth (in.) } & \multicolumn{4}{|c|}{ Year Germinated } \\
\hline & \multicolumn{2}{|c|}{ Seed 1-yr old } & \multicolumn{2}{|c|}{ Seed recently harvested } \\
\hline & 1952 & 1953 & 1952 & 1953 \\
\hline $\begin{array}{l}\text { Surface...... } \\
0.25 \ldots \ldots \\
0.5 \ldots \ldots \\
1.0 \ldots \ldots \\
2.0 \ldots \ldots \\
3.0 \ldots \ldots \\
4.0 \ldots \ldots \\
5.0 \ldots \ldots \\
6.0 \ldots \ldots\end{array}$ & $\begin{array}{r}2.0 \\
11.5 \\
64.0 \\
45.0 \\
57.0 \\
38.0 \\
12.5 \\
1.2 \\
0.2\end{array}$ & $\begin{array}{l}4.6 \\
2.3 \\
1.4 \\
6.3 \\
0.0 \\
0.8 \\
- \\
- \\
-\end{array}$ & $\begin{array}{r}1.5 \\
22.0 \\
24.5 \\
22.5 \\
39.5 \\
22.5 \\
- \\
-\end{array}$ & $\begin{array}{r}4.1 \\
4.5 \\
10.6 \\
5.0 \\
14.9 \\
7.7 \\
- \\
- \\
-\end{array}$ \\
\hline
\end{tabular}

Table 8. Percentage germination of seed of leafy spurge of various ages stored and germinated at room temperature.

\begin{tabular}{|c|c|c|c|}
\hline \multirow[b]{2}{*}{ Age in years } & \multirow[b]{2}{*}{$\begin{array}{l}\text { No. of } \\
\text { seeds }\end{array}$} & \multicolumn{2}{|c|}{ TIME INTERVAL } \\
\hline & & $\begin{array}{c}\text { Two } \\
\text { weeks }\end{array}$ & $\begin{array}{l}\text { Two, 2-week periods } \\
\text { interrupted by } 1 \\
\text { week of drying }\end{array}$ \\
\hline $\begin{array}{r}\text { Newly-harvested... } \\
1, \ldots \ldots \ldots \ldots \\
2 \ldots \ldots \ldots \ldots \\
5 \ldots \ldots \ldots \ldots \\
8 \ldots \ldots \ldots \ldots \ldots\end{array}$ & $\begin{array}{r}50 \\
50 \\
100 \\
50 \\
100 \\
100\end{array}$ & $\begin{array}{r}6 \\
34 \\
3 \\
24 \\
10 \\
1\end{array}$ & $\begin{array}{r}18 \\
40 \\
6 \\
26 \\
10 \\
2\end{array}$ \\
\hline
\end{tabular}


germinated more completely than that which was recently-harvested or 2-years old. They revealed also that germination may be $10 \%$ or more until the 8 th year and that some viability remains after 13 years. Dormancy appeared to be a factor of some importance even in the oldest samples, since further germination was promoted after 1 week of drying (Table 8).

\section{Scarification}

To discover whether seed coat condition is responsible for dormancy, seeds were scarified by rubbing between sheets of sandpaper and vigorous shaking in a glass jar for 1 minute. During a period of 4 years following seeding in the field, a higher percentage of seedlings were produced from untreated seeds. The depressing effect of the treatment may have been associated with damage inside the seed coat or by the subsequent activity of microorganisms. In any event, the intact seed coat did not appear to be of consequence in relation to dormancy.

\section{Temperature}

In an experiment involving 1,800 seeds from Site No. 1, samples representing 3 different ages germinated more completely at $32^{\circ} \mathrm{C}$ than at $22^{\circ} \mathrm{C}$ during a period of 2 weeks (Table 9). Highest germination percentages were obtained from the alternation of exposure to these temperatures. Similar results were obtained in an experiment involving 1,400 seeds at temperatures of $20^{\circ}$ and $30^{\circ} \mathrm{C}$. The majority of the seed in these tests germinated within a 2 -week period. At higher temperatures, however, an additional 2 weeks promoted further germination, suggesting a progressive breakdown of seed dormancy.

In a further series of experiments involving 5,000 seeds (of the highly viable type from Site No. 1), germination was more complete at a temperature of $25^{\circ} \mathrm{C}$ than at $20^{\circ} \mathrm{C}$, at $30^{\circ}$ than at $20^{\circ}, 25^{\circ}$ or $40^{\circ} \mathrm{C}$, and at alternating 20 and $30^{\circ} \mathrm{C}$ than at continuous $30^{\circ} \mathrm{C}$ (Table 10). Germination failed to oc-

Table 9. Percentage germination of seed of leafy spurge of various ages when exposed to temperatures of $22^{\circ} \mathrm{C}$ and $32^{\circ} \mathrm{C}$ at 2-week intervals. Results are based on duplicate samples of 200 seeds for each treatment.

\begin{tabular}{|c|c|c|c|}
\hline \multirow[b]{2}{*}{ Treatment } & \multicolumn{3}{|c|}{ Age in Years } \\
\hline & $\begin{array}{c}\text { Newly- } \\
\text { harvested }\end{array}$ & 1 & 2 \\
\hline 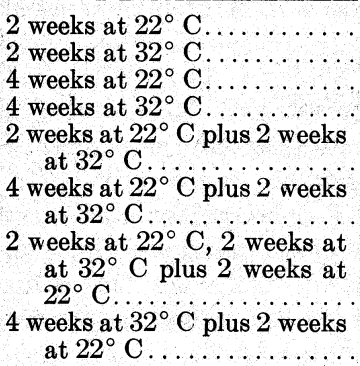 & $\begin{array}{r}9.5 \\
37.0 \\
14.0 \\
58.5 \\
80.0 \\
68.5\end{array}$ & $\begin{array}{l}28.5 \\
80.0 \\
29.0 \\
83.5 \\
87.0 \\
58.5 \\
88.0 \\
84.5\end{array}$ & $\begin{array}{l}25.0 \\
48.0 \\
25.0 \\
68.0 \\
64.5 \\
67.0\end{array}$ \\
\hline
\end{tabular}

Table 10. The effect of temperature on the germination of leafy spurge seed.

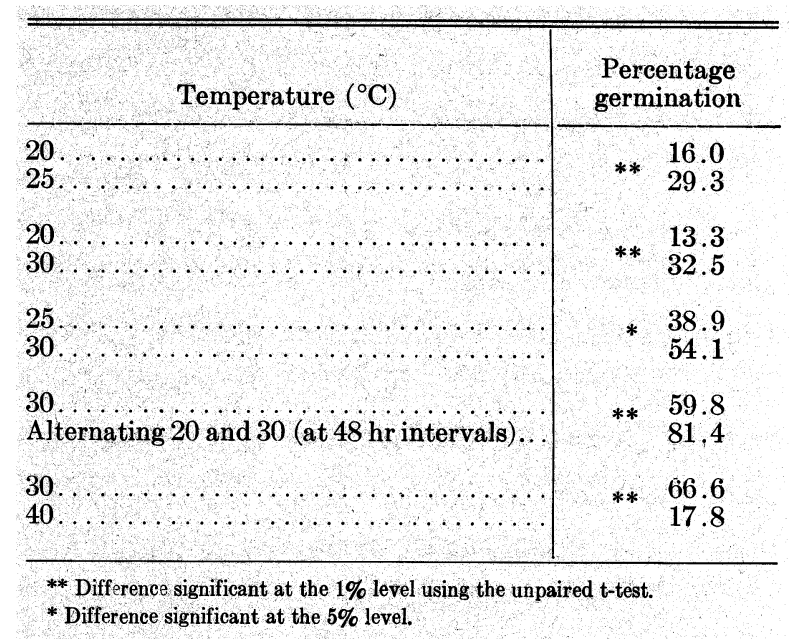

Page 13 of 45 
cur when seeds (400) were subjected to a temperature of $45^{\circ} \mathrm{C}$ and only 1 of 400 seeds germinated at a temperature which varied between $8^{\circ}$ and $12^{\circ} \mathrm{C}$. That more complete germination than this does sometimes occur at low temperatures is reported by Brown and Porter (1942) who obtained $3 \%$ germination at $5^{\circ} \mathrm{C}$ and $0.5^{\circ} \mathrm{C}$. In the present experiments, germination was possibly promoted (but not significantly) by alternating temperatures between $30^{\circ}$ and $0^{\circ} \mathrm{C}$ for 48 -hour periods, but not between $20^{\circ}$ and $0^{\circ} \mathrm{C}$.

A temperature of $30^{\circ} \mathrm{C}$ appears to be near optimum for germination, but better results can be expected from alternating temperatures in the range from $20^{\circ}$ to $30^{\circ} \mathrm{C}$. These conclusions are in agreement with those of Hanson and Rudd (1933) and of Brown and Porter (1942).

\section{Light}

In another experiment, light was found to be a significant factor in retarding germination (Table 11). Continuous light was supplied by a 100watt incandescent bulb and darkness maintained by a layer of black paper placed over the seed in petri plates. It appears from the data that this effect of light operates within a considerable range of temperatures (from $20^{\circ}$ to $40^{\circ}$ C at least).

\section{Seed maturity}

During maturation, the immature yellow seeds change in colour gradually to brown, then grey, and finally to brown mottled (Wicks and Derscheid 1958). The most mature seeds have been referred to previously as "brown" (Bakke 1936, Selleck 1958), but the term "mottled" is a more accurate description. Ripened seed samples invariably include both grey and mottled seeds. The rate of development of seeds in individual capsules is usually uniform. An examination of 185 capsules revealed only one instance where seeds of different colours (brown and grey) were present in the same capsule. Not a single grey seed was found in fully ripened capsules ready for dehiscence. The more advanced stage of maturity of mottled seeds resulted in a significant increase in weight. At one site the mottled seeds weighed $373.4 \mathrm{mg} / 100$, compared to $315.6 \mathrm{mg}$ for grey seeds. Similar seed weights were recorded from a second site. These observations agree with those of Bakke (1936).

The heavier, more mature, mottled seeds germinated significantly better than grey seeds at temperatures of $30^{\circ} \mathrm{C}$ and $25^{\circ} \mathrm{C}$. An increase in germination with increase in seed weight has been reported previously (Hanson and Rudd 1933, Bakke 1936), but is not in agreement with data presented by Wicks and Derscheid (1958), who found that grey seeds germinated more completely than mottled.

Page 14 of 45 
To compare the effect of degree of maturity on imbibition, grey and mottled seeds were separated from samples collected (at Site Nos. 1 and 2) in 1953. That the decreased germination of grey seeds is not related to impermeability of membranes to water is indicated by a comparison of the rate of imbibition of grey and mottled seeds (Table 12).

The percentage imbibition of grey seeds consistently and significantly exceeded that of mottled. Imbibition was rapid during the first 6 hours $(30$ to $45 \%$ gain in weight) and continued for an additional 42 hours. Maximum imbibition was reached just prior to the emergence of the radicle from germinable seed and after the same period of soaking in seed which failed to germinate. The amount of imbibition was higher in the present series of experiments than that reported by Bakke (1936), who obtained a $6 \%$ increase in weight after 122 hours. Bakke's results conflict with the present data in that he reported greater absorption with brown (mottled) seeds. He concluded that germinability was positively correlated with absorption and reported that increases in both absorption and germination occurred with increasing temperature, to reach a maximum between $28^{\circ}$ and $31^{\circ} \mathrm{C}$.

\section{Moisture relations}

The present authors found that alternate periods of wetting and drying at 48-hour intervals in petri plates at $20^{\circ}$ and $30^{\circ} \mathrm{C}$ did not significantly affect germination. The slight depression in germination, which was observed due to the treatment, may indicate that a moist period of 48 hours is insufficient for germination to be fully initiated.

Bakke (1936) reported that seeds of leafy spurge float on water and germinate better in this medium than on moist blotting paper. During the present study, seed of 2 ages germinated in 0.5 inch of water in petri plates, but the level of germination was lower than that obtained on filter paper in other experiments. Some germination occurred on the water surface, some beneath. After 5 days, $3 \%$ of the seed had germinated and more than $60 \%$ had settled to the bottom of the dish. At the end of 14 days, the samples had germinated approximately $13 \%$ and all of the seed had settled to the bottom. The turbulence of running water along a drainage channel would probably keep the seeds afloat for a longer period of time, providing an opportunity for seedlings to become established after being deposited along the bank. Bakke (1936) has commented on the high incidence of leafy spurge in water-washed areas in Iowa. This was noticeable also in Saskatchewan. An infestation may follow a drainage pattern for 200 yards but not infest to any extent the banks on either side. The ability of the seed to float and germinate in water appears to be

Page 15 of 45 
particularly advantageous for establishment of the species in areas which are occasionally subjected to flooding.

\section{Inhibition by salts}

The effect of concentration of salts in the soil solution on germination is of significance in relation to the use of soil sterilants in the control of this weed. Bakke (1936) found that some salts were more effective than others in preventing germination. As the concentration of a solution of sodium chlorate was increased, germination decreased until it was completely inhibited at a 0.1 molar concentration. With calcium chloride, a 0.2 molar concentration was necessary for complete inhibition. Bakke found that the amount of absorption decreased with increased concentration, but the percentage increase in weight of seeds remained approximately the same. When field infestations were sprayed with sodium chlorate, the percentage germination was very low, and immature seeds germinated better than mature ones. The effect of salts used as herbicides was studied also during the present investigation. Sodium chlorate was applied to leafy spurge (at Site No. 5) in sufficient concentrations to kill the plants. Two years later the area supported a dense mat of seedlings, numbering up to 70 shoots per sq $\mathrm{dm}$. Only a small proportion of these survived and developed. Similarly, with the application of sodium and calcium metaborates (at Site No. 6), seedlings germinated and developed from 2 to 3 years after application of the herbicide, presumably after it leached from the surface layers of soil.

Several factors in nature appear to reach an optimum simultaneously for germination of the seed. Within 12 months after dehiscence of the seed it is covered by a layer of debris, which reduces light intensity, retains moisture, and within 1 year has decomposed sufficiently to provide a suitable substratum for germination at a time when conditions within the seed are most favourable.

\section{Seedling and shoot development}

Absorption of water often causes the testa to break in a germinable seed within 12 to 24 hours. The tip of the radicle then appears as early as 12 hours after the eruption of the seed coat. Root hairs develop from 12 to 24 hours later, when the radicle has reached a length of approximately $1 \mathrm{~cm}$. The radicle usually develops to a length of $1.9 \mathrm{~cm}$ within 2 days after the seed coat has broken. The hypocotyl develops within 12 hours after the appearance of root hairs. When the seed germinates in soil, the loop of the hypocotyl is the first to emerge from the surface and within 24 hours becomes erect, revealing the cotyledons enclosed within the seed coat. Within an additional 24 hours, the seed coat is sluffed off and the cotyledons function as leaves.

Hanson and Rudd (1933) have described stems of seedlings as being pink in colour at the time of emergence. The present authors observed that the loop of the hypocotyl was pink, but the stem turned green within 2 days. Kummer (1951) has described the hypocotyl as being pale green above ground and a dull reddish brown at the soil line. The latex system develops from a few initials in the embryo of the seed (Haberlandt 1914), originating from a few specialized cells in the cotyledonary node (Cummings 1941), and is present in the young stem at the time of emergence. 
Under greenhouse conditions seedlings developed rapidly, producing 4, 6, 8,10 and 12 leaves within 6 to 10,10 to 21,13 to 24,17 to 26 and 21 to 31 days, respectively, after emergence from the soil surface. At 24 days, the respective lengths of root and stem averaged 7 inches and 2.5 inches (Table 13). The first 2 leaves are opposite, but the remainder are distinctly alternate. The leaves are bluish-green in colour on the upper surface and paler green below. A bloom of minute granules covers the upper surface. Vegetative buds developed on each of the seedlings just above the soil surface at an age of 10 to 12 days or when 6 leaves were present. The number of buds on 60 seedlings averaged 4.7 per seedling at 15 days and 5.6 at 35 days. The average heights of these shoots were 3.8 inches and 6.4 inches respectively. Under field conditions, shoots which were 7 days old with 4 leaves produced vegetative buds. To determine at what stage seedlings were capable of vegetative reproduction, seedlings in the greenhouse at various stages between 6 and 10 leaves were severed above the buds at the soil surface, and others below the buds at a depth of 0.5 inch below the soil surface. Of 22 seedlings in the leaf stage which were cut below the buds, 11 produced new shoots. Nine of 15 seedlings which were severed above the buds on the same date, also developed. All of the seedlings survived when severed in the 10-leaf stage at a depth of 0.5 inch under field conditions, regrowth occurred from $5 \%$ of the roots of 7-day-old seedlings which were severed 1 inch below the soil surface.

Under field conditions, the seedling develops an extensive root system within a relatively short period. Within 2 months after the appearance of the cotyledons, the root systems of the most vigorous seedlings have been reported to penetrate to a depth of 24 inches and to produce stems 5 inches tall (Hanson and Rudd 1933). Seedlings grown by Pavlychenko and Harrington (1938) produced roots to this depth at the age of 1 month. In 4 months the roots of these seedlings penetrated 39 inches vertically, occupied an area 35 to 39 inches in diameter, and attained a total length of 1,095 feet. These data were obtained from an infestation (in silty clay loam soil) which was free from competition from
Table 13. The length of root and shoot (inches) of leafy spurge at various ages. Seedlings were grown in the greenhouse in 1952.

\begin{tabular}{|c|c|c|c|}
\hline Age (days) & $\begin{array}{l}\text { Length of } \\
\text { root }\end{array}$ & $\begin{array}{c}\text { Length of } \\
\text { shoot }\end{array}$ & $\begin{array}{l}\text { Total } \\
\text { length }\end{array}$ \\
\hline $\begin{array}{r}1 \ldots \\
2 \ldots \\
10 \ldots \\
11 \ldots \\
17 \ldots \\
24 \ldots\end{array}$ & $\begin{array}{l}1.0 \\
2.5 \\
4.0 \\
4.5 \\
5.0 \\
7.0\end{array}$ & $\begin{array}{l}0.5 \\
0.7 \\
1.5 \\
2.0 \\
3.0 \\
2.5\end{array}$ & $\begin{array}{l}1.5 \\
3.2 \\
5.5 \\
6.5 \\
8.0 \\
9.5\end{array}$ \\
\hline
\end{tabular}

Fig. 2. The development of leafy spurge seedlings at ages of 1, 2, 10,11, 17, 24 and 31 days under greenhouse conditions.

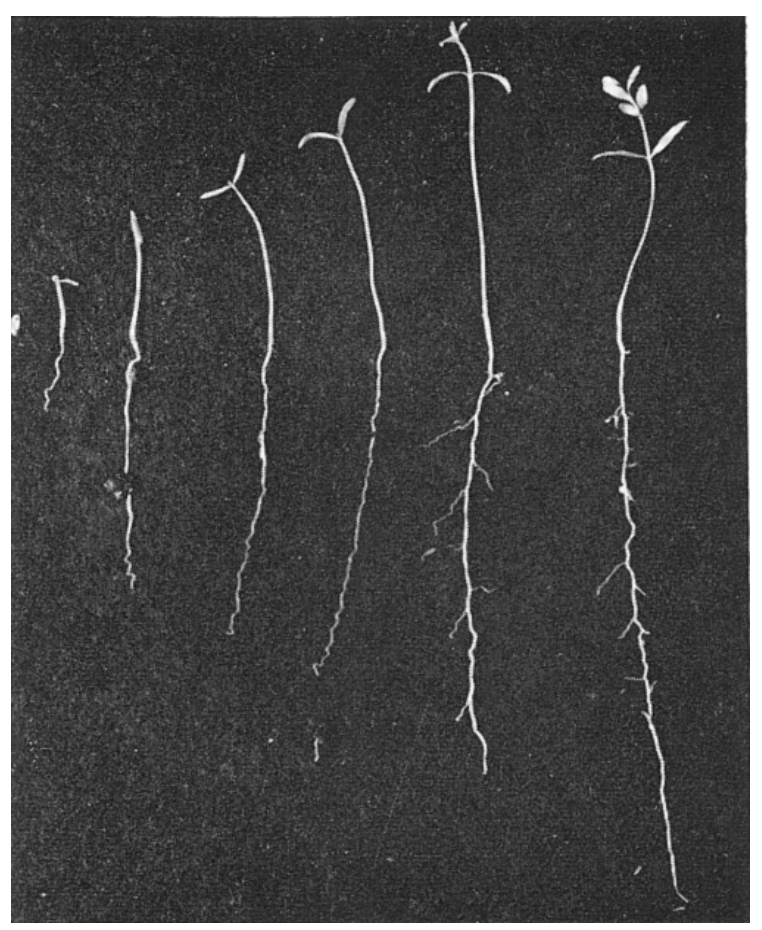


other species. Competition results in survival of only a small proportion of the seedlings. The number of seedlings averaged 28/sq dm on May 27, 1951 in a natural infestation near Site No. 5. During the next month some of these seedlings died and others emerged, resulting in a $11.6 \%$ net decrease in mean density. Seedlings which were 1.0 to 1.5 inches in height on May 27 reached a height of 3 inches 1 month later. In June, the shoots were lacking in vigour, stunted, and chlorotic. By September 12, the number of seedlings had decreased to $5 / \mathrm{sq} \mathrm{dm}(500 / \mathrm{sq} \mathrm{m})$ representing a decrease of $82 \%$. The vigorous survivors had reached a height of 11 inches, but there was no sign of inflorescence development. In an artificial infestation (at Saskatoon), shoots developed from seedlings during the first year, reaching an average height of 14 inches, but also failed to produce an inflorescence until the second year.

Vegetative shoots of leafy spurge emerge earlier in spring than seedlings, initiating growth in southcentral Saskatchewan between April 17 and May 1. These shoots develop from vegetative buds which are located at or just below the soil surface.

After stems of leafy spurge begin to deteriorate in the fall, buds which are located on rhizomes and roots near the soil surface begin to enlarge. With the onset of cold weather, the plant remains dormant until the following spring. In Saskatchewan, 2-inch sections of rhizomes, removed from a field infestation in October and transplanted to pots in the greenhouse, regenerated readily and produced mature seed by mid-December. Continuous shoot development occurred in pots for 24 months (from November 1951 until October 1953), but inflorescences failed to develop. These pots were placed in the field in summer and in the greenhouse during the winter months. The underground parts in check pots which were kept out-of-doors were unable to withstand the rigours of winter.

\section{Roots and their reproductive capacity}

Many authors have attributed the persistence of leafy spurge to the morphological and physiological characteristics of its root system. The thick, tough stele and the thick, corky bark of the older root portions provide strength and sufficient insulation to maintain normal activities within the root, despite unfavourable root-water relationships. Pavlychenko and Harrington (1938) have demonstrated that no roots died within the first 6 years during the development of plants. The enormous reservoir of food located in the phloem, cortex, and pith of the root (Bakke 1936) contributes to the survival of the weed over long periods of unfavourable conditions.

A very dense interlacing network of roots and rhizomes occurs to depths of 4 feet and roots sometimes penetrate 15 feet (Bakke 1936). Hanson and Rudd (1933) reported that the transition zone between stem and root extends to a depth of 1 foot in North Dakota, but in Saskatchewan it was observed to occur between 3.7 and 5.5 inches (Bakshi and Coupland 1959). During the present study, production of underground parts totalling $8,492 \mathrm{lb} /$ acre was measured to a depth of 48 inches, the majority of which $(56.2 \%)$ was confined to the surface 6 inches (Coupland and Alex 1954). The proportion of roots decreased with depth from $16.8 \%$ in the 6 - to 12 -inch layer to $2.4 \%$ in the 42 - to 48 -inch layer.

Page 18 of 45 
Soil texture was found to have no significant effect on the total weight, but influenced distribution of the underground parts. Coarse-textured soils contained a higher proportion of roots in the surface 6-inches layer and in layers below 30 inches than did fine textured soils, so that weights were almost double in $\mathrm{C}$ horizons of the former as compared with $\mathrm{C}$ horizons of fine-textured soils. Recent cultivation adversely affected root development. The weight of underground parts of the weed at all levels in native grassland was approximately twice that of areas which had been recently cultivated.

The presence of vegetative buds on the roots is considered to be a major factor in the persistence of the species. The numbers of buds in 6-inches soil layers is associated with the weight of the root material present, which tends to be greatest just below the soil surface, and decreases with increasing depth (Coupland and Alex 1955). The average number of buds per root decreased from 6.92 in the surface 1-inch layer of soil to 1.56 in the 11- to 12-inches layer (Coupland et al. 1955). Buds have been found to a depth of 10 feet in the soil (Bakke 1936). No relationship existed between the location of the lime layer and the number of buds occurring at any level in the soil (Coupland et al. 1955). The profuse bud development on underground parts of this species may be attributed to their origin from a pericyclic ring of phellogen in the roots (Bakshi and Coupland 1959).

The capacity of underground parts to produce new shoots from various depths was also assessed. Some of the results have already been reported (Coupland et al. 1955). The results of experiments using an improved technique are presented in Table 14. "Excavated plots" were established by removing soil and roots of leafy spurge to depths of 1,2 and 3 feet, cribbing the holes with sections of steel barrels, and refilling them with tamped, uninfested soil in order to simulate natural compaction. "Buried plots" consisted of sections of steel barrels placed on the undisturbed surface and filled to the same depths in a similar manner. At every location, in both treatments,

Table 14. Mean number of shoots of leafy spurge which emerged from 2.64 sq. ft. excavated and buried plots at four locations during 1952-1956. The experiments were initiated in 1951.

\begin{tabular}{|c|c|c|c|c|c|c|c|}
\hline \multirow{2}{*}{ Depth (in ft) } & \multirow{2}{*}{$\begin{array}{c}\text { Stage of } \\
\text { development }\end{array}$} & \multicolumn{5}{|c|}{ YEAR } & \multirow{2}{*}{ Mean } \\
\hline & & 1952 & 1953 & 1954 & 1955 & 1956 & \\
\hline \multicolumn{8}{|l|}{ Excavated plots } \\
\hline \multirow[t]{2}{*}{1} & Flowering & 2.5 & 3.5 & 9.5 & 7.5 & 9.7 & 6.5 \\
\hline & Non-flowering & 21.7 & 54.2 & 55.7 & 46.0 & 41.5 & 43.8 \\
\hline \multirow[t]{2}{*}{2} & Flowering & 0.0 & 0.5 & 2.0 & 4.3 & 8.0 & 3.0 \\
\hline & Non-flowering & 6.0 & 18.7 & 19.0 & 7.5 & 16.8 & 13.6 \\
\hline \multirow[t]{2}{*}{3} & Flowering & 0.0 & 0.0 & 0.0 & 0.0 & 1.3 & 0.3 \\
\hline & Non-flowering & 0,5 & 1.0 & 1.2 & 1.0 & 0.5 & 0.8 \\
\hline \multicolumn{8}{|l|}{ Buried plots } \\
\hline \multirow[t]{2}{*}{1} & Flowering & 6.5 & 9.0 & 21.7 & 24.0 & 18.3 & 15.9 \\
\hline & Non-flowering & 21.0 & 54.5 & 34.5 & 41.0 & 57.0 & 41.6 \\
\hline \multirow[t]{4}{*}{2} & Flowering & 0.0 & 8.2 & 20.2 & 14.0 & 16.3 & 11.7 \\
\hline & Non-flowering & 17.0 & 30.7 & 34.5 & 4.0 & 39.7 & 25.2 \\
\hline & Flowering & 0.0 & 0.0 & 1.0 & 3.5 & 0.3 & 1.0 \\
\hline & Non-flowering & 0.5 & 7.7 & 22.0 & 16.0 & 0.0 & 9.2 \\
\hline
\end{tabular}

Fig. 3. Shoots of leafy spurge (Site No. 1), which in 12 months have grown through 2 feet. of tamped soil in a barrel placed above the surface.

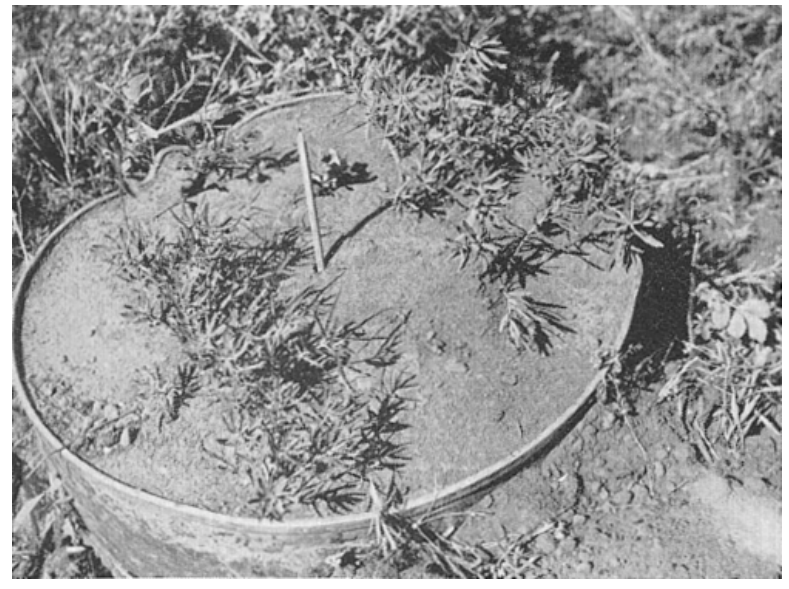


shoots were able to penetrate 2 feet of soil within 12 months (Table 14). Shoots emerged through 1 foot of dense soil within 116 to 133 days at some sites and produced seed the same season. Only at 2 sites were shoots able to emerge through 3 feet of soil in either the buried or excavated plots.

The mean density of regrowth was not decreased by 1 foot of soil in buried plots ( 58.0 shoots $/ 2.64$ sq feet), but the density in excavated plots was decreased by $13 \%$. The effect of the treatment became greater with increased depth of burial, particularly in the excavated plots. Nevertheless, some shoots were able to emerge even from the small proportion of the root system which remained below the 3-foot level excavated plots. The removal of part of the root system had a greater effect on reducing the number of flowering shoots than of non-flowering ones.

The shoots were traced down each year to locate their origin, but were not removed. In this operation numerous unemerged shoots were encountered. In the 3-foot plots more unemerged shoots were sometimes found close to the soil surface than emerged above it. Following regrowth of shoots in the 1-foot and 2-foot plots, new crowns were formed near the soil surface, from which regrowth occurred the following year. This explains the rapid recovery of the weed from these drastic treatments. However, in the 3-foot plots, shoots emerged from the 3-foot level each year without developing crowns. In the buried plots winter exposure 2 to 3 feet above the field surface may have been a factor, although the barrels were banked with earth. Shoots did not always survive after emergence, particularly from the greater depths. The erosive effect of sand grains propelled by the wind at this height ( 2 or 3 feet above the surrounding terrain) may have been significant also in the failure of emerging shoots to survive. The unemerged shoots were white and brittle in character, with the tips bent into a loop by the force exerted in the elongation of the stem. This loop straightened out after reaching the soil surface. Occasionally branches occurred on shoots in the soil as a result of a temporary delay in growth (Fig. 4). Small, yellowish-green leaf scales from 0.25 to 0.6 inch long and 0.06 inch wide appeared on the shoots to a depth of 15 inches beneath the soil surface. Buds which occurred in the axils of the leafy scales appeared 2.5 inches below the surface and extended to a depth of 32 inches

Fig. 4. Shoots of leafy spurge which failed to penetrate the soil surface in a barrel 2-feet above ground (Site No. 2). The shoot on the right grew 8 inches, producing 3 branches at that point. The shoot on the left reached a length of 14 inches before producing 5 branches.

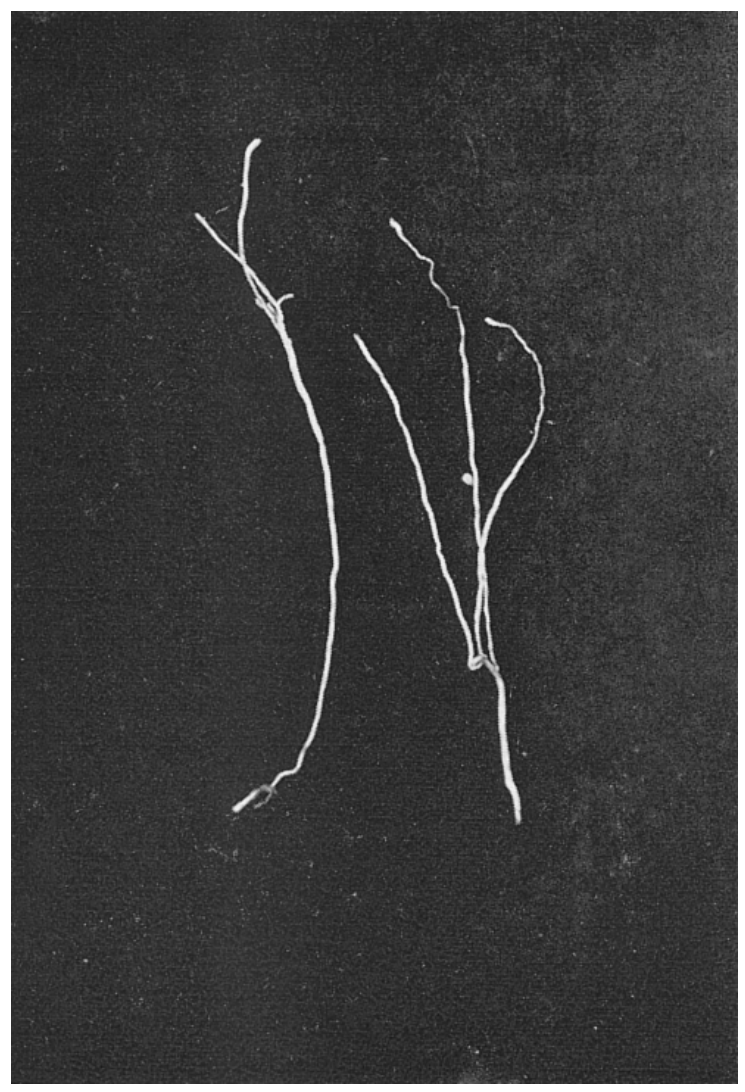


at average intervals of 1.5 inches.

Shoots which emerged appeared to be of the same thickness from the point of origin to the surface, while roots decreased in size with increasing depth. After plants were established for more than 1 year, the crown became enlarged. The buds which developed in each successive year were generally located at a lower level than those which were formed the previous year. Sometimes, however, a new shoot occurred on the stem of the shoot of the previous, year, providing it was located beneath the soil surface. After the brittle, white shoots reached the surface, a protective, brown, bark began to form around the underground parts. This protective bark first appeared near the soil surface, and became patchy with increasing depth. Bark formation was nearly complete when the shoot reached the flowering stage. Bark formation was present on the underground portion of flowering shoots, except near the point from which regrowth originated, but gaps occurred in the bark on non-flowering shoots.

The most significant result of these experiments was the demonstration of the ability of the roots to produce vegetative shoots for 5 successive years from a depth of 3 feet after the major portion of the root system had been removed. This performance is outstanding when consideration is given to the fact that no horizontal roots occur in leafy spurge below this depth to permit lateral translocation of nutrients from outside the plot. This demonstrates the great reproductive capacity of roots under adverse conditions.

Tillage and disturbance have been reported previously to affect the underground parts in such a manner as to increase the density of shoots (Hanson and Rudd 1933). A field trial conducted (at Site No. 6) on sandy-loam soil in 1957 shows that regrowth following roto-tilling averaged 316 shoots/sq $\mathrm{m}$ as compared to 134 in the undisturbed check. Further observations concerning the effect of disturbance were made by severing the root system in soil monoliths at depths of 12, 24 and 36 inches Cutting increased the number of shoots which were produced by roots 1 to 2 inches below each cut. Shoots were produced in unsectioned monoliths in the greatest numbers from the soil surface to a depth of 5 inches, being most frequent between the 2-inch and 4-inch levels (Coupland et al. 1955).

The remarkable ability of the underground parts to reproduce explains the difficulty which has been experienced in eradicating leafy spurge by tillage, digging and burial.

\section{Inflorescence development}

The first shoots to appear above ground each spring are from the perennial underground parts. The date of first emergence at Saskatoon ( $52^{\circ} \mathrm{N}$ Lat) ranges between April 17 and May 1. This is approximately 1 week later than the date of appearance reported in North Dakota (47 $\mathrm{N}$ Lat) (Hanson and Rudd 1933) and approximately 2 weeks later than that observed in Wisconsin ( $43^{\circ} \mathrm{N}$ Lat). After a period of 5 to 7 days, a swelling occurs in the apex of the shoot, marking the initiation of the inflorescence. The outermost bracts of the bud open from 8 to 14 days later. Development of a compound umbellate inflorescence then begins. Several new terms are suggested to describe its complex development and arrangement. The first inflorescence which develops is referred to as the "centrecyathium" and usually consists of a single female flower and from 12 to 20 male flowers. The female flower often fails to develop at this stage, or sometimes the males fail to ap-

Page 21 of 45 
pear. After the initiation of the centrecyathium, the development of the compound inflorescence proceeds in rapid succession, and when completed resembles an inverted pyramid. From 3 to 5 days after the appearance of the "centre" female flowers, from 5 to 12 buds (which are located at its base) enlarge, and the bracts open simultaneously to reveal female flowers representing the "centrepaired" stage of development. At this stage, a female flower rarely fails to appear. The male flowers usually emerge within 2 to 4 days and produce pollen. At the base of each centre-paired flower, 2 buds develop female flowers representing the "paired" stage. Elongation of the pedicels of the umbel accompanies development of the centre-paired flower. These pedicels attain a length of 0.5 inch in 3 days, 1 inch in 11 days, and at maturity are 3 to 4 inches long. The maximum length of pedicels of centre-paired flowers is 1.5 inches

The interval between each successive wave of female flowers varies from 5 to 15 days. At approximately mid-June, development proceeds with 2 buds at the base of each "paired" flower, representing the "quad" stage (Table 15). Further development produces the "octet" stage, and later the "duo-octet" stage with 16 flowers for each pedicel of the umbel. This stage is rarely produced under Saskatchewan field conditions. According to Knuth (1909) all of the native European spurges possess the same flower arrangement.

The date of first appearance of the inflorescence varies between May 5 and late May. The shoots are about 10 inches tall when the first flowers appear (Table 15). The stigmas open, and become receptive to pollen from 1 to 3 days after emergence of the female flower. From 3 to 8 days later, the glands of the cyathium begin secreting nectar. Inversion of the female flower then occurs (to occupy a space between the glands) and is usually accompanied by closing of the stigmas and the appearance of 1 or 2 male flowers. Occasionally a male flower appears prior to inversion. On the day following inversion, from 2 to 5 male flowers appear, reaching a total of 11 to 20 within 3 days. The interval between the appearance of female and male flowers varies from 1 to 5 days in the greenhouse and from 2 to 13 days under field conditions. Cool weather retards this development. When the female flowers fail to appear, males usually fail to develop also.
Table 15. Shoot and flower development of leafy spurge from April 24 to June 21, 1956 at Saskatoon.

\begin{tabular}{|c|c|c|}
\hline Date & $\begin{array}{l}\text { Shoot } \\
\text { height } \\
\text { (in.) }\end{array}$ & Stage of development and remarks \\
\hline pril 24 & $\frac{3}{4}$ & Shoots reddish in color. \\
\hline May 2 & $\frac{3}{4}$ & $\begin{array}{l}\text { Shoots reddish in color. (Cold weather } \\
\text { April } 25 \text { to May } 2 \text { delayed develop- } \\
\text { ment). }\end{array}$ \\
\hline May 5 & 1 & Shoots green. \\
\hline May 10 & 4 & Some flower buds at apex of shoot. \\
\hline May 14 & 6 & Budding general. \\
\hline May 18 & 9 & Terminal leaves of bud beginning to open. \\
\hline May 20 & 10 & $\begin{array}{l}\text { Terminal leaves open; center cyathium } \\
\text { showing; female flower absent. }\end{array}$ \\
\hline May 22 & - & $\begin{array}{l}\text { Some centre male flowers present, some } \\
\text { centre-paired bracts beginning to open, } \\
\text { female flower absent. }\end{array}$ \\
\hline May 24 & 14 & $\begin{array}{l}\text { Centre-paired bracts opening on adjacent } \\
\text { shoots, female flower visible. }\end{array}$ \\
\hline May 25 & - & $\begin{array}{l}\text { Centre-paired male flowers present where } \\
\text { female failed to develop, stigmas open } \\
\text { on neighboring centre-paired female } \\
\text { flowers. }\end{array}$ \\
\hline May 29 & - & $\begin{array}{l}\text { Centre-paired female inverted, males pres- } \\
\text { ent. }\end{array}$ \\
\hline June 2 & - & $\begin{array}{l}\text { Some stigmas open, some closed on in- } \\
\text { verted centre-paired females, some } \\
\text { paired bracts beginning to open, fe- } \\
\text { males present. }\end{array}$ \\
\hline June 5 & - & $\begin{array}{l}\text { Some centre-paired capsules developing; } \\
\text { some paired stigmas opening. }\end{array}$ \\
\hline June 6 & 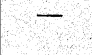 & $\begin{array}{l}\text { Paired stigmas open, some inverted with } \\
\text { males present, a few developing pollen. }\end{array}$ \\
\hline June 8 & - & $\begin{array}{l}\text { Paired females inverted, some males de- } \\
\text { veloped ripe pollen. }\end{array}$ \\
\hline $\begin{array}{c}\text { June } 9 \\
\text { - }\end{array}$ & - & $\begin{array}{l}\text { Centre-paired capsules one-half size, be- } \\
\text { coming erect; paired females inverted, } \\
\text { males developed ripe pollen. }\end{array}$ \\
\hline June 14 & 16 & $\begin{array}{l}\text { Some centre-paired capsules dead, some } \\
\text { developing seed; some paired capsules } \\
\text { developing; some quad females present. }\end{array}$ \\
\hline June 21 & 18 & $\begin{array}{l}\text { Paired capsules fully developed; some quad } \\
\text { capsules developing; many octet buds } \\
\text { present, some cyathia open, displaying } \\
\text { flowers of both sexes. }\end{array}$ \\
\hline
\end{tabular}


Occasionally, however, male flowers develop within 2 to 5 days after the appearance of the cyathium. Certain isolated infestations (presumably of 1 clone) in Saskatchewan have been found to produce female flowers only, but the dioecious character is rare in this species.

Mature pollen is found on the anthers from 24 to 48 hours after the emergence of the male flower. Pollen becomes inviable after 2 days, and within 2 to 5 days, the male flowers become detached at the base. One or 2 stigmas of the style are sometimes pollinated without pollen being deposited on the others, resulting in a partially developed capsule. Unpollinated flowers die from 5 to 23 days after emergence. The ovaries of pollinated ones begin to expand within 5 to 14 days after emergence. As expansion continues, the ovaries again assume an erect position. Under greenhouse conditions, capsules attain maximum development within 10 to 16 days, and from 21 or 22 days under field conditions. Ripe seed was produced and dehisced 27 days after the appearance of the female flower in the greenhouse and from 20 to 31 days in the field.

Flowering generally ceases in terminal inflorescences between the end of June and the middle of July. The development and maturation of the seed extends approximately 30 days beyond the appearance of the last flower. Consequently, flower production and seed development is continuous from late April until mid-August, the first seeds having

Fig. 5. The development of lateral branches on a shoot of leafy spurge as a result of mowing. The photograph was taken September 8, 1954.

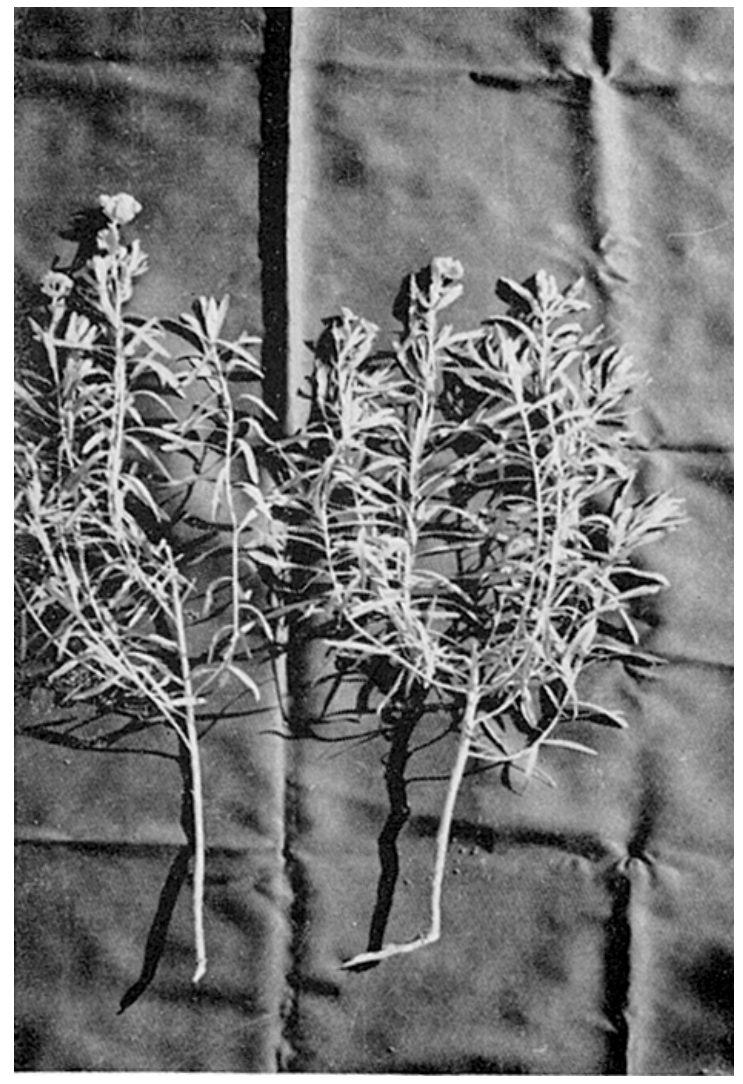

Fig. 6. Green shoots of leafy spurge terminated by dried-up umbels (August 30, 1954.)

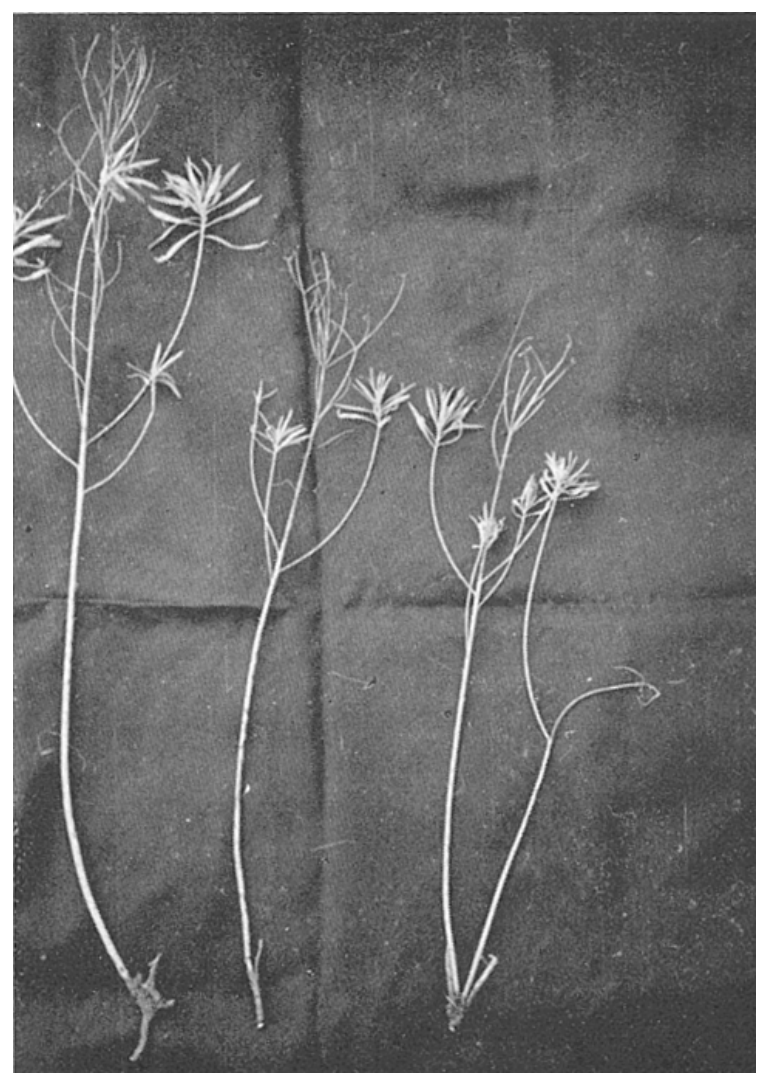


ripened in July. Under favorable conditions, inflorescence and seed production continue from lateral branches until freeze-up in late October or November. Development of lateral inflorescences is usually similar to that of the pedicel on terminal inflorescences but occasionally umbels develop on lateral inflorescences also.

Shoots developing after top removal by mowing or grazing in the early part of the growing season, produce inflorescences only on lateral branches. The removal of the terminal bud results in profuse branching. Spring tillage, or a single application of 2,4-D, merely delays seed production. Fall frosts kill inflorescences and inhibit latex production. Observations at 4 sites for 7 years revealed that seed dispersal occurred between August 1 and September 30. The dried-up umbels persist on the leafy shoots throughout the remainder of the growing season. (Fig. 6).

\section{Pollination}

Female flowers generally develop and become inverted before the male flowers appear. Nevertheless, occasionally a single male flower develops before inversion, suggesting that self-pollination is not impossible. Pollination appears to be accomplished almost entirely by insects. The inversion of the female flower (which prevents contact with the male) and the clinging of pollen in sticky masses, suggest that wind is not the transporting agent. The production of nectar by involucral glands and its availability at the time of pollen dehiscence indicates that insects are the pollinating agent. Bakke (1936) found that, after isolation of 2 plants of leafy spurge with fine wire cages for 3 weeks, seed production was prolific outside of the cages but absent on isolated plants. He concluded that insects were necessary for pollination. To check this in the present study, 30 shoots were individually isolated with a 28 -mesh screen. Seed failed to develop, except on 4 shoots, while seed production was normal outside of the cages. An ant (Lasius sp.) was observed on the inflorescence of 1 of the isolated shoots and may have been responsible for the limited pollination. This ground-dwelling ant is abundant on sandy soils in Saskatchewan and has often been observed feeding on the nectar of leafy spurge. It may, therefore, be of considerable importance in pollination. Bees, flies, and mosquitoes have been observed to feed on the nectar also. Further evidence of the role of insects in pollination is apparent from the failure of seed production in greenhouses free of insects. After a housefly was observed to be feeding on nectar from a plant in the greenhouse, however, capsules were produced by all 22 flowers present.

Several other insects have been reported to be associated with pollination of leafy spurge and related species. Knuth (1909) states that certain Euphorbia spp. are pollinated exclusively by flies and that beetles, wasps and bees are occasional visitors. Bakke (1936) reports several species of Diptera, Hymenoptera and an unknown species of lygus bug as visitors. Insect populations were examined during the present study in 4 locations, in which a total of 240 sweeps were taken with a net (Table 16). Representation by Hymenoptera and Diptera were most numerous. In addition to insects, 8 spiders were found in the collections.

Page 24 of 45 
Wind may be responsible for pollination through accidental contact of flowers, but not by actual transport of pollen. This was demonstrated by subjecting a cluster of shoots to the air movement caused by an 8-inch fan. Following this treatment 3 capsules formed, presumably as a result of accidental contact of the stigmas and anthers. Lack of seed production in the greenhouse without pollination, dismissed the possibility of parthenocarpy.

Pollen is yellow when immature and becomes orange and sticky when ripe. It is at this stage (at approximately 24 hours after emergence of the stamen), that pollen is most viable and the grains adhere to one another in sticky masses. Pollen is viable from 12 to 48 hours after appearance of the anther. Viability is low with bright yellow, immature grains and dark orange, over mature ones.

Although Bakke (1936) reported that the female flower becomes inverted only after it has been pollinated, observations during the present study showed that inversion of the female flower occurs in the field or in the greenhouse whether it has been pollinated or not. When the female flower is not pollinated it inverts, dries up, and drops off. Female flowers are more receptive to pollen when they are erect than when they are inverted, and the opening of the 3 stigmas indicates maximum receptivity. Flowers are still receptive to pollen, however, after inversion occurs.

Thus, the mechanism of pollination in leafy spurge is such as to minimize selfpollination. The present experiments have shown also that a higher percentage of fertility is obtained by cross-pollination. Artificial pollination was conducted on 125 female flowers on normal flowering stalks in the greenhouse. Only $28 \%$ of the flowers produced seed when pollinated by males on the same cyathium. Since female flowers were usually inverted with stigmas closed before ripe pollen was available, it was necessary to remove male flowers with tweezers, to force open the stigmas, and place the pollen directly in contact with the stigmas. Two or 3 males were used for pollination of each female. When inflorescences were selfed (pollen obtained from male flowers anywhere on the same shoot) $41.3 \%$ of the flowers produced seed. When pollen was obtained from a different plant, seed was produced by $56.4 \%$ of the flowers.

\section{Seed production and capsule dehiscence}

The fruit develops from a superior, 3-celled ovary which has central placentation. The 3-lobed capsule, containing 1 to 3 seeds, dehisces when ripe. Four-celled capsules are not uncommon and were abundant in 1 isolated patch. Five-celled capsules have been observed on 2 occasions. The seeds apparently develop very rapidly, since they have been reported to become viable from 10 to 13 days following inversion of the capsule (Wicks and Derscheid 1958).

Page 25 of 45 
Under normal conditions, individual seed stalks produce from 10 to 50 fruits, usually with 3 seeds each (Bakke 1936). In 1951, 10 shoots of leafy spurge were selected at regular intervals along line transects at 5 sites of the Saskatchewan study, and the numbers of capsules were counted. The highest average seed yield (252/shoot) was obtained in competition with native grass. Yields of 212 and 196 seeds per flowering shoot were measured, respectively, in competition with annual weeds and crested wheat grass. The effect of competing crested wheat grass in reducing seed yield is illustrated by measurements (on sandy loam soil at Site No. 3) during 1951, 1952 and 1953. The yields of leafy spurge in a mixed stand with forbs and shrubs were 496, 98 and $45 \mathrm{lbs} /$ acre, respectively. Reductions in yield where crested wheat grass was the chief competitor were 11, 85 and 55\%.

In calculating seed yields on the basis of numbers of seeds on sampled stems, large variations were encountered. In one instance a stem bearing 426 seeds was found in a stand averaging 168 seeds/stem. The weight/100 seeds was measured in only 1 stand, where 5 samples averaged $250 \mathrm{mg}$. This is lower than the weight of $350 \mathrm{mg} / 100$ seeds reported in North Dakota (Stevens 1932). The yield of seed within patches in various Saskatchewan stands was calculated to range from 24 to 3,400 lbs/acre. The highest yield occurred where a stand in native grass had been mowed, resulting in removal of the apical meristem and stimulation of the development of inflorescences on numerous lateral branches.

Three infestations were found in which seed production apparently did not occur. In one of these stands, observed for 8 years, a few capsules were noted only once, but no evidence that seeds developed. The reason suggested for the sterility was absence of male flowers. Presumably the infestations had each developed from individual clones, one being spread by tillage implements to occupy 30 acres. Further evidence of the long-term sterility of these infestations was obtained in the failure of soil screening to locate seed and of seedlings to emerge from soil placed in favourable greenhouse conditions. When these clones were grown at Saskatoon in proximity to normal ones, they developed capsules containing seeds, despite the continued absence of male flowers in these abnormal clones. The $F_{1}$ plants grown in the greenhouse from this seed produced male flowers which contained viable pollen, suggesting that the lack of male flowers in the abnormal clones is due to an inherited recessive factor. However, in the greenhouse the abnormal clones also produced some male flowers, but the (lighter in colour than normal) pollen (from 35 flowers) was found to be sterile when used in hand pollination (while normal pollen produced capsules in $24 \%$ of the flowers).

An examination of the contents of 185 capsules from one collection revealed that $78 \%$ produced 3 seeds, while 17 and $4 \%$ respectively, contained 2 seeds and 1 seed. Less than $1 \%$ of those capsules which developed were completely sterile. Some capsules attained $1 / 3$ to $1 / 2$ size before aborting.

Seeds are 2.0 to $2.5 \mathrm{~mm}$ in length, $1.5 \mathrm{~mm}$ wide, oval in outline, almost circular in cross-section, sometimes oblong or broadly wedge-shaped with a prominent disc-like caruncle at the narrow end. The seed coat is faintly reticulated, chalky grey to various shades of yellow and brown, frequently with reddish spots (Murley 1945). A brown raphe extends from base to apex, terminating at the prominent yellow tubercle, the caruncle. 
Bakke (1936) has described the morphology of the capsule. The walls are comprised of 3 distinct layers of columnar cells. The inner layer of contractile tissue consists of 3 or 4 rows of columnar cells $48 \mu$ thick, with their axes arranged longitudinally. The middle layer of parenchymatous tissue is $150 \mu$ thick, consisting of a single tier of radially arranged cells. The outer layer, which contains chlorophyll in the younger stages of capsule development, is $80 \mu$ thick with cells imbricated horizontally towards the lodicular suture. At maturity, these cells lose water and upon drying tend to pull the edges of the locule together, straining the whole capsule. The capsule then ruptures with an explosive force which hurls the seeds for distances up to 15 feet (Bakke 1936) and distributes them uniformly (Hanson and Rudd 1933). The eruption of the capsule results in the 3 carpels splitting away from the central axis. Occasionally the individual dehisced carpels remain intact with the seed enclosed. A small opening remaining in each carpel indicates the position of the carpel in relation to the central axis. More often the eruption of the capsules results in splitting of the individual carpels to free the seed completely. When this happens each half of the carpel resembles a twisted wing-like structure.

High temperatures and low humidity dry out the cells of the capsule and trigger its eruption. Bakke (1936) reports that most of the seeds are dehisced after 2:00 P.M. The wind apparently has some influence on the direction of dissemination (Hanson and Rudd 1933). Under the relatively arid field conditions in Saskatchewan, dehiscence occurred during both morning and afternoon on sunny days. Eruption of ripe capsules did not occur on cloudy days, but resumed after $1 / 2$ hour of sunshine. The snapping of the dehiscing capsules was clearly audible. Under laboratory conditions, when the capsules have dried out adequately, a temperature of $80^{\circ} \mathrm{F}$ trips the dispersal mechanism. This was demonstrated by bringing ripe capsules into a warm room within a few hours of collection. Within 30 minutes, the heat from a desk lamp, which was located approximately 18 inches above them, dried out the capsules sufficiently to trigger the dispersal mechanism. Seed dehiscence may be promoted by storing the capsules in paper bags in a warm place.

\section{Seed dispersal}

Wild and domestic animals, birds, and insects are agents of seed dispersal. Overgrazing by livestock provides bare areas which are suitable for the establishment of seedlings. Leafy spurge has sometimes invaded vigorous native grassland from seedlings which became established in the proximity of rodent diggings. Indirect evidence of distribution by animals is provided by the report of a farmer who observed that the pattern of the plants in his field coincided with the path of accidental dragging by a cultivator of the buried entrails of a deer. Batho (1932) states that domesticated livestock may also be an agent of migration.

The activity of birds as disseminators of seeds of leafy spurge has been suggested because of frequent feeding, particularly of "mourning doves", on the seeds (Bakke 1936, Clute 1937, Bellue 1946). However, no seeds were viable in the digestive tracts of 14 doves, although seeds from the crop germinated 17\% (Bakke 1936). The conclusion is that this bird may be instrumental in destroying vast quantities of seed, since Bakke (1936) claims that it feeds on leafy spurge almost exclusively when seed is abundant. This bird was observed to feed on leafy spurge during the present study, both in Sas- 
katchewan and Wisconsin. The possibility that doves distribute seed remains because of regurgitation when feeding its young (Ashbrook), which provides an opportunity for seeds to drop to the ground.

It has been suggested that ants play a role in the dispersal of seed of leafy spurge. Ridley (1930) reports that ants are among the most important dispersers of seed. The wood ant (Formica sp.) is reported to carry elaiosome-bearing seeds, to eat the oil body and to drop the seed. Seeds of E. peplus and E. segetalis have been found in ant nests (Dymes, as reported by Ridley 1930). The ground ant (Lasius sp.) is abundant and the mound ant (Formica sp.) common in leafy spurge infestations on coarse-textured soil. It is conceivable that they play some part in distribution of the seed. Mound ants use stems of this plant in the construction of their mounds and it is possible that some seed capsules may be intact.

An experiment was conducted to ascertain whether ants would store leafy spurge seed or feed on the elaiosomes. Seeds were placed in and around some of the ant burrows and mounds in infestations at Site Nos. 2, 3 and 6. The process was repeated twice during the summer of 1956. The Lasius ants carefully removed the seed from their burrows, but otherwise ignored it throughout an observation period of approximately 1 hour. They were, however, immediately attracted to, and began to feed on, bits of meat, bread and sugar. The Formica ants removed the seed which had fallen into the burrows, and many of them carried it to the perimeter of the ant hill and dropped it over the edge. Most of the ants ignored seed which was on top of the mound. Under these conditions the ants showed no inclination either to feed on the elaiosomes or to store the seed in their burrows.

\section{Ecological relations}

The vigour displayed by leafy spurge in various habitats indicates adaptation to a wide range of conditions. Since the natural vegetation of the area infested in Saskatchewan is principally grassland, particular attention should be given to the competition of this weed in relation to both native and introduced grasses. This factor is of economic significance because of the vigorous competitive ability exhibited by grasses and the possibility that they may be useful in the control of this weed.

\section{Density relationships}

The effect of native and seeded grasses in modifying the density of leafy spurge was studied at 5 sites. While it was not always possible to make comparisons of the behaviour of the weed in the absence of grasses, 2 of the sites included areas which had been recently abandoned from tillage and thus supported very little grass. Density measurements were made from 1951 to 1958 and involved counting the number of shoots of the various species in an average of $139 \mathrm{sq} \mathrm{m}$ quadrats annually in 13 locations. The present report is a summary of only a portion of the data.

The density of leafy spurge fluctuated considerably during this period, with no apparent trend being observed. In most situations no further increases in density occurred after a population of 200 shoots/ sq $\mathrm{m}$ had been reached. The percentage cover of grasses 
tended to increase during the study period (Table 17). Brome grass is evidently not able to compete effectively against this weed. Where this grass increased in density during the study period (Site Nos. 1 and 2), the density of leafy spurge was not adversely affected; where the density of brome grass remained low (Site No. 4), that of leafy spurge increased substantially, so that 1 quadrat in July 1953, supported more than 2,400 shoots/ sq $\mathrm{m}(40 \%$ of which were seedlings).

Table 17. The mean number of shoots per sq. $m$ of leafy spurge in various habitats during 1951-1958 and the basal area of grass at the beginning and end of the study.

\begin{tabular}{|c|c|c|c|c|c|c|c|c|c|c|c|}
\hline \multirow{2}{*}{ Habitat } & \multicolumn{2}{|c|}{ BasAL Cover of } & \multicolumn{8}{|c|}{ YEAR } & \multirow{2}{*}{ Mean } \\
\hline & $\begin{array}{c}\text { Begin- } \\
\text { ning }\end{array}$ & End & 1951 & 1952 & 1953 & 1954 & 1955 & 1956 & 1957 & 1958 & \\
\hline \multicolumn{12}{|l|}{ Brome grass } \\
\hline Site No. 1. & 2.5 & 7.6 & 74.5 & 38.5 & 105.5 & 109.5 & 73.0 & 44.3 & 84.5 & - & 75.7 \\
\hline $\begin{array}{l}\text { Site No. } 2 \ldots \ldots \\
\text { Site No. } 4\end{array}$ & 6.1 & 12.8 & $\overline{-10} 0$ & 120.6 & 126.6 & 131.2 & 111.0 & 114.8 & 96.6 & - & 116.8 \\
\hline \multicolumn{12}{|l|}{ Crested wheat grass, Site No. 3} \\
\hline $\begin{array}{l}\text { Leafy spurge } 100+\text { per sq } m . \\
\text { Leafy spurge } 1-99 \text { per sq }\end{array}$ & 4.0 & 3.7 & 224.0 & $\begin{array}{r}170.6 \\
-8\end{array}$ & 207.6 & 214.6 & 174.2 & 308.7 & - & 215.8 & 216.6 \\
\hline \multicolumn{12}{|l|}{ Native grasses } \\
\hline Site No. $1 . .$. & 3.4 & 5.4 & 73.5 & 63.5 & 110.8 & 92.2 & 115.5 & 06.2 & 119.4 & 120.3 & 98.9 \\
\hline $\begin{array}{l}\text { Site No. } 2 \ldots \\
\text { Site No. } 3\end{array}$ & 4.2 & 14.8 & 45.7 & 42.0 & 42.3 & 46.3 & 37.0 & 36.0 & 33.3 & - & 40.4 \\
\hline \multirow{2}{*}{\multicolumn{12}{|c|}{$\begin{array}{l}\text { Abandoned land } \\
\text { Site No. } 3\end{array}$}} \\
\hline & & & & & & & & & & & \\
\hline $\begin{array}{l}\text { Leafy spurge } 100+\text { per sq } \mathrm{m} . \\
\text { Leafy spurge } 1-99 \text { per sq } \mathrm{m} . .\end{array}$ & 0.0 & 5.2 & 170.0 & 197.2 & 224.2 & 216.4 & 191.4 & 256.8 & - & 198.8 & 207.8 \\
\hline $\begin{array}{l}\text { Leary spurge 1-99 per sq } \mathrm{m} \text {. } \\
\text { Site No. } 5\end{array}$ & & & 14 & 19 & 45.4 & 59 & 73.0 & 102.0 & - & 85.2 & 57.0 \\
\hline Leafy spurge $1-35$ per sq $\mathrm{m} .$. & - & - & 19.1 & 38.0 & 56.9 & 69.4 & 109.3 & 121.2 & 144.2 & - & 79.7 \\
\hline Leafy spurge $36-99$ per sq $\mathrm{m}$. & - & - & 61.5 & 84.5 & 102.0 & 112.0 & 162.9 & 179.9 & 199.4 & - & 128.9 \\
\hline Leafy spurge & - & - & 122.5 & 125.5 & 141.3 & 156.7 & 202.8 & 241.6 & 207.7 & - & 171.1 \\
\hline
\end{tabular}

The wide range of density in this site (No. 4) permitted the comparison of the relative competitive ability of leafy spurge in sparse versus dense stands of the weed. Quadrats were divided into 2 groups on the basis of the density of shoots exceeding 2 inches in height: those containing less than 100 shoots/sq $\mathrm{m}$ and those with 100 shoots or more. The shoots less than 2 inches in height were included in a separate category, since most of them were seedlings. The density averaged 230/sq $\mathrm{m}$ in dense quadrats in 1951 and increased $389 \%$ by 1953 . The number of brome grass shoots averaged $46 / \mathrm{sq} \mathrm{m}$ in 1952 and increased 3.3\% the following year. A similar trend occurred in sparse quadrats. The density of shoots varied between $988 / \mathrm{sq} \mathrm{m}$ in the centre of the patch, to 20 shoots/sq $\mathrm{m}$ at the perimeter. Brome grass in this location did not, therefore, check the increase in density of the weed in even the sparsely infested area.

The maximum density of leafy spurge was reached at the above site in competition with brome grass on heavy clay soil. This density was more than 3 times that which occurred at any other site. The increase in density of vegetative shoots in 1952 could be accounted for by the establishment of $22.1 \%$ of shoots less than 2 inches tall which were present the previous year. The remaining $77.9 \%$ did not survive. The increase in density of vegetative shoots in 1953, however, could not be fully accounted for by the complete establishment of shoots less than 3 inches tall from the previous year. Increases in density were due, therefore, partly to establishment of seedlings and partly to increased vegetative production from established underground parts. 
Crested wheat grass is apparently no more effective than brome grass in reducing the density of a thick stand of leafy spurge, but it is capable of limiting the rate of increase of sparse stands (Table 17). Although this grass had the capacity to establish from seed in stands of leafy spurge, its basal area increased substantially only in sparse stands of the weed and remained constant in dense stands. This grass invaded sparse stands more rapidly than dense ones. As already discussed, competition by crested wheat grass is manifest also through decreased seed production and a decrease in vigour of top growth. Although Pavlychenko (1942) demonstrated that under certain conditions competition by crested wheat grass substantially reduced the density of leafy spurge in 4 years, suppression to this degree was not evident in the present study. Pavlychenko's infestation was an artificial one which was established in silty clay loam at Saskatoon. The relatively poor performance of the weed in his experiments may have been due to poor adaptability of his clones to this soil type.

Densities of leafy spurge increased markedly during the study period in an abandoned field at Site No. 5, where density was recorded annually in $65 \mathrm{sq}$ m quadrats during 1951 to 1957. Quadrats were divided into 3 density classes on the basis of the number of shoots present in 1951: 1-35, 36-99 and 100+/sq m. After 1955, the densities had increased, so that all of the quadrats were in the $100+$ density class. The density of shoots in the lowest category (1-35) had increased by more than 6 times during 1951-1957.

The vigour of the competing species appeared to have a profound effect upon the proportion of flowering shoots of the weed. During 1951 to 1956 the proportion of flowering shoots averaged almost $80 \%$ in competition with native grasses, compared with $4 \%$ in competition with crested wheat grass. By 1956 flowering shoots were absent in sparse stands where the weed was in competition with crested wheat grass. Such decreases in the proportion of flowering shoots appeared to be correlated with increases in grass cover. This observation is corroborated by Bakke (1936), who reports that "under unfavourable conditions the species may cease to grow and fail to produce an inflorescence." The proportion of flowering shoots averaged $14 \%$ of the total number of vegetative shoots in competition with brome grass in 1951 and increased slightly during the next 2 years. In a recently abandoned field (Site No. 5) the percentage of flowering shoots decreased from $71 \%$ in 1951 to $37 \%$ of the total in 1957 . The percentage of flowering shoots was higher in dense stands of leafy spurge than in sparse stands, regardless of competing vegetation (other than crested wheat grass).

When light is limiting, the percentage of flowering shoots is decreased. Nonflowering shoots survive in aspen groves, but development of inflorescences is inhibited. At Site No. 1, where a De Jur light meter registered $60 \mathrm{fc}$ in the open, leafy spurge was flowering at a reading of $6 \mathrm{fc}$. Vegetative shoots survived until the shade of aspen reduced the reading below $3 \mathrm{fc}$. The weed responded similarly to light in oak woods in Wisconsin, where it produced seed in a light intensity of $10 \mathrm{fc}$, compared with a reading of $65 \mathrm{fc}$ in the open. The density of non-flowering shoots was maintained at 80 to 100/sq $\mathrm{m}$ at a reading of 4 , but few shoots were present at an intensity of $2 \mathrm{fc}$.

Other factors also affect the proportion of flowering shoots. The percentage of flowering shoots at Site No. 5 increased markedly during the first year of study (probably as a result of cessation of tillage) and decreased in subsequent years as succession progressed from predominantly annual to perennial species. The increase in density of the weed itself 
may contribute to the decrease in proportion of flowering shoots through an increased demand on the factors of the habitat. Moisture may be sufficiently limiting to prevent the development of the inflorescence.

The density of leafy spurge seedlings varied considerably from one site to another and from year to year. One patch in a favourable location at Site No. 1 supported a mean of 92 seedlings/sq $\mathrm{m}$ during a 5-year period, while the driest habitat at the same site averaged 1.6 seedlings/sq $\mathrm{m}$. During the same period the number of seedlings at Site No. 3 averaged $31 / \mathrm{sq} \mathrm{m}$ in dense stands of the weed on an abandoned field, which was more than 4 times the density of seedlings in any other habitat in the area. Seedling density was particularly low in competition with native grass and in sparse quadrats of leafy spurge in competition with crested wheat grass. At Site No. 4 in competition with brome grass, however, the population of seedhingsatewtsan edseekhergerqatebabtlyabecause of the heavy production of seed from the dense stand of flowering shoots and the favourable conditions for germination offered by the clay soil (Table 6). The mean density/sq m averaged 551 in 1951, and decreased by $81 \%$ by 1953 . Seedling densities paralleled densities of vegetative shoots. Seedlings averaged $1,073 / \mathrm{sq} \mathrm{m}$ in dense quadrats compared with $31 / \mathrm{sq} \mathrm{m}$ in sparse quadrats and decreased by 74 and $37 \%$, respectively, during a 2 -year period.

The density of leafy spurge varies from year to year and does not seem to be consistently influenced by competing factions of the vegetation. At Site No. 1, for instance, densities of leafy spurge and competing grasses varied from year to year, but ultimately increased in 4 of 6 patches. These increases occurred in different patches in different years. Some of these fluctuations in density were perhaps due to the effect of grazing. At Site No. 2, however, an equilibrium appears to have been reached between leafy spurge and the competing species. The increase in grass cover which occurred may be due partly to improved moisture conditions and partly to the cessation of grazing. At 2 locations, the density of the weed was maintained at a lower level in competition with native species of grass than in competition with brome grass, possibly because the native grass sites were situated on south-facing slopes. It is possible, however, that brome grass may be less effective as a competitor than native species. The order in which species become established may influence density. Native grasses were present prior to the establishment of introduced grasses. The density of the weed may be more easily restricted by an established stand of grass, than decreased by an introduced competitor after establishment. The 
ability of crested wheat grass to restrict the density of leafy spurge in a sparse stand of the weed, but not to decrease the density in a dense stand, tends to support this concept.

Table 18. The mean number of shoots per sq. $m$ and the number of species of annual, biennial and perennial shoots competing with leafy spurge in various habitats at the beginning and end of the study period.

\begin{tabular}{|c|c|c|c|c|c|c|c|c|}
\hline \multirow{3}{*}{ Habitat } & \multicolumn{4}{|c|}{ Beginning of Study Period } & \multicolumn{4}{|c|}{ End of Study Period } \\
\hline & \multicolumn{2}{|c|}{ Annual } & \multicolumn{2}{|c|}{ Biennial and perennial } & \multicolumn{2}{|c|}{ Annual } & \multicolumn{2}{|c|}{ Biennial and perennial } \\
\hline & Species & Shoots & Species & Shoots & Species & Shoots & Species & Shoots \\
\hline 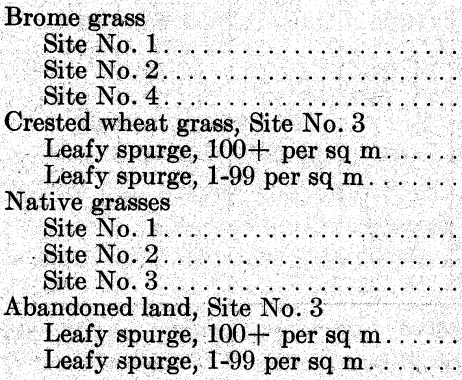 & $\begin{array}{r}1 \\
2 \\
3 \\
\\
2 \\
4 \\
0 \\
0 \\
1 \\
9 \\
13\end{array}$ & $\begin{array}{r}1.1 \\
7.0 \\
7.5 \\
127.2 \\
79.0 \\
0.0 \\
0.0 \\
2.8 \\
81.2 \\
277.0\end{array}$ & $\begin{array}{r}16 \\
15 \\
2 \\
3 \\
3 \\
3 \\
\\
2 \\
4 \\
6 \\
5 \\
5 \\
9\end{array}$ & $\begin{array}{r}13.3 \\
73.6 \\
35.5 \\
28.0 \\
42.6 \\
8.3 \\
28.3 \\
18.0 \\
45.8 \\
81.0\end{array}$ & $\begin{array}{l}0 \\
0 \\
5 \\
1 \\
0 \\
0 \\
0 \\
1 \\
1 \\
0\end{array}$ & $\begin{array}{l}0.0 \\
0.0 \\
0.5 \\
2.2 \\
0.0 \\
0.0 \\
0.0 \\
0.6 \\
0.4 \\
0.0\end{array}$ & $\begin{array}{r}27 \\
8 \\
8 \\
3 \\
2 \\
2 \\
2 \\
8 \\
3 \\
5\end{array}$ & $\begin{array}{r}19.7 \\
20.1 \\
32.8 \\
6.6 \\
12.0 \\
6.0 \\
23.3 \\
28.7 \\
14.8 \\
30.2\end{array}$ \\
\hline
\end{tabular}

As a result of competition from leafy spurge and grasses, the number of species and shoots of other forbs and shrubs present in the infestations decreased during the study period (Table 18). Annual species virtually disappeared at all study sites. The most important species at these sites were as follows:

Chamaerhodos nuttali ${ }^{6}$

Potentilla sp.

Artemisia frigida

Astragalus sp.

Anemone patens var. wolf gangiana

Symphoricarpos occidentalis

Rosa spp.

Helianthus tuberosus

Cerastium arvense

Solidago dumetorum

Elaeagnus commutata

Antennaria microphylla

Achillea lanulosa

Comandra pallida

Agoseris glauca

Viola adunca

\footnotetext{
${ }^{6}$ Fernald (1950) was the authority used for names of forbs and shrubs. Rydberg (1932) was followed for those species not included by Fernald.
} 


\section{Thermopsis rhombifolia}

\section{Solidago missouriensis var. fasciculata}

\section{Vicia americana}

Many of these were represented at all study locations. There were 37 additional species which were of minor importance, some of which disappeared as a result of competition.

\section{Rate of spread}

Leafy spurge displays a remarkable capacity for vegetative reproduction. Throughout this investigation it continued to spread by this means in every habitat each year (Table 19). The periphery of each patch was mapped annually from 1951 to 1958 at approximately the same time each year. The mean rate of spread was determined from approximately 5,000 comparisons made at 2-foot intervals, involving the position of outermost shoots in 1 year as compared with a former year. These maps were drawn in relation to a grid, except at 1 site where the outline of each patch was related to a central point.

The weed was able to spread every year in competition with all other species in the study areas. The average annual spread within stands of introduced grass was less (1.64 feet) than in unseeded abandoned cropland (2.03 feet) and in ungrazed native grassland (2.09 feet). Considerable variation occurred in the average gains made in different habitats in different years, the range being from 0.27 to 4.14 feet (Table 19).

Table 19. The mean rate of spread (increase in radius) in feet of patches of leafy spurge in various habitats during 1951-1958.

\begin{tabular}{|c|c|c|c|c|c|c|c|c|c|}
\hline \multirow{2}{*}{ Habitat } & \multicolumn{7}{|c|}{ YEAR } & \multirow{2}{*}{ Total } & \multirow{2}{*}{ Mean } \\
\hline & 1952 & 1953 & 1954 & 1955 & 1956 & 1957 & 1958 & & \\
\hline $\begin{array}{l}\text { Field abandoned 1950, Site No. } 5 \text {. } \\
\text { Field abandoned 1949, Site No. } 3 .\end{array}$ & $\begin{array}{l}1.74 \\
1.93\end{array}$ & $\begin{array}{l}3.03 \\
2.89\end{array}$ & $\begin{array}{l}2.64 \\
2.75\end{array}$ & $\begin{array}{l}2.21 \\
2.20\end{array}$ & $\begin{array}{l}1.68 \\
2.34\end{array}$ & 1.82 & $\overline{1}^{1.16^{1}}$ & $\begin{array}{l}13.12 \\
13.27\end{array}$ & $\begin{array}{l}2.19 \\
1.89\end{array}$ \\
\hline Native grassland ungrazed, Site No. 3. & 2.35 & 3.29 & 2.54 & 2.36 & 2.62 & 1.65 & 2.45 & 17.26 & 2.47 \\
\hline $\begin{array}{l}\text { Native grassland ungrazed, Site No. } 2 \text {. } \\
\text { Native grassland grazed, Site No. } 1\end{array}$ & 2.46 & 1.86 & 2.00 & 2.23 & 0.45 & 0.85 & - & 9.85 & 1.64 \\
\hline Flowering shoots............... & 2.17 & 1.43 & 1.85 & 1.61 & 2.40 & 1.93 & 4.14 & 15.53 & 2.22 \\
\hline $\begin{array}{l}\text { Non-flowering shoots. . .......... } \\
\text { Field abandoned } 1949 \text {, seeded to crested }\end{array}$ & - & - & 3.75 & 1.97 & 2.16 & 1.19 & 3.14 & 12.21 & 2.44 \\
\hline wheat grass, Site No. $3 \ldots \ldots \ldots$ & 0.27 & 1.52 & 2.36 & 1.13 & 1.77 & - & $1.46^{1}$ & 8.51 & 1.21 \\
\hline $\begin{array}{l}\text { Brome grass, Site No. } 4 . \\
\text { Brome grass Site No. } 2\end{array}$ & 1.24 & 1.51 & & & & & & 2.75 & 1.38 \\
\hline $\begin{array}{l}\text { Brome grass, Site No. } 2 \\
\text { Flowering shoots.... }\end{array}$ & 2.78 & 1.39 & 1.17 & 2.53 & 2.22 & 1.63 & - & 11.72 & 1.95 \\
\hline Non-flowering shoots. & - & - & 3.67 & 0.88 & 3.13 & 0.39 & 1.98 & 10.05 & 2.01 \\
\hline
\end{tabular}

1 Total spread during 1957-1958.

Data concerning rate of lateral spread were also obtained at several sites by the line transect method (Table 20). Fewer measurements were obtained by this method than by mapping, but the magnitude of the values was similar. Only in one instance did an increase fail to occur. 
Considerable variation occurred in the rate of radial increase on different sides of the same patch and between different patches in the same type of habitat, as well as in different habitats (Fig. 8). For example, the greatest increase recorded at Site No. 3 was 11.0 feet along one edge of a patch, when the weed gained as little as 0.2 feet elsewhere in the same patch during the same year. The maximum increase in radius rarely occurred in the same direction in the same patch in consecutive years. The greatest rate of spread in nearby patches usually occurred in different directions in the same year. As a result, no significant difference was found between the total extent of lateral spread in various directions during the 5-year period. The fluctuation in the boundary of flowering shoots was even greater than for non-flowering ones. The latter always marked the position of greatest advance of patches.

Occasionally the boundary of a patch was found to have retreated at some locations from the position it occupied during the preceding year. The greatest recession (3.2 feet) occurred at Site No. 3 in competition with crested wheat grass in 1952. In 1955, where the area of one patch at Site No. 1 remained unchanged, vegetative shoots extended as much as 2.4 feet at one part of the margin and retreated up to 4.0 feet at another. Similarly, 2 years later in the same patch, vegetative shoots invaded 9.2 feet at one location, and retreated 3.1 feet at another. These recessions were only temporary and were not associated with deterioration of underground parts.

Because of the zig-zag course of advancing rhizomes, the linear distance involved in the spread of vegetative shoots is actually greater than that indicated by annual measurements. The mean increase in radius which occurred at one site in 1956 was 0.45 feet. When the means of the monthly values were added together, the mean increase in radius was 0.90 feet. Similarly in 1957 , the sum of the monthly increases was 1.49 feet compared with an actual mean increase of 0.85 feet.

Under favourable moisture conditions, patches continue to extend their borders throughout the entire growing season. Increases were recorded (at Site No.5) during the moist August and September of 1953, while (at Site No. 2) a patch expanded consistently from June until August and receded during dry weather from August to September of 1956. The same patch, however, continued to spread throughout the moist weather of the next autumn.

Page 34 of 45
Table 20. The mean rates of spread (in feet) of leafy spurge in various habitats during 1956-1958.

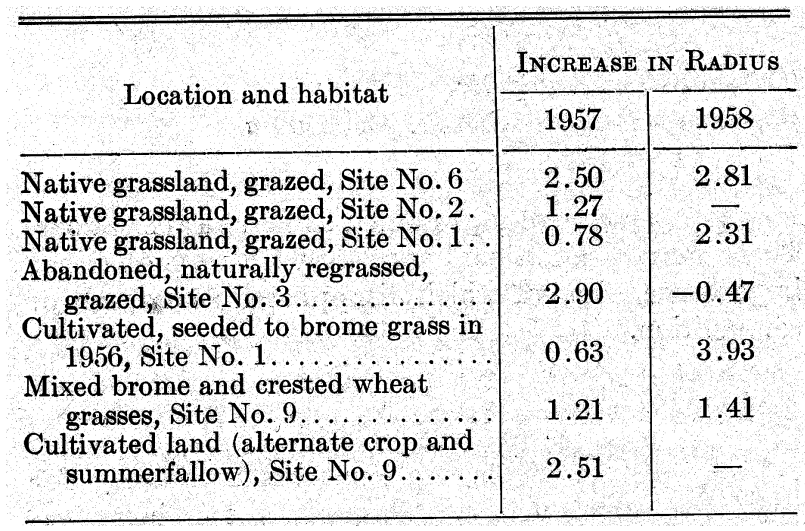


To observe the initial rate of spread by seedlings, 100 seeds were planted in a 6-foot row in the Saskatoon plots in May 1951. Only 7 seedlings emerged, and they reproduced vegetatively, to occupy an area of $2 \mathrm{sq}$ feet by fall. At the end of 5 years the patch had increased in area to occupy $470 \mathrm{sq}$ feet. This rate of spread is about equivalent to that reported by Kirk et al. (1940), where a patch spread from 1 seedling to occupy an area of soil 18 feet in diameter in 4 years. Including the added lateral spread of the root system, the patch increased to 24 feet in diameter.

Consideration was given to the effect of lateral spread in relation to the radial increase in extent of patches. The rate of increase in area of small patches was much greater than that of large ones, since rapidity of radial growth is related to the circumference rather than to the area. For example, a patch which occupied $7 \mathrm{sq}$ feet in 1951, increased in area by 387 times in the next 5 years, while a nearby patch, which occupied $781 \mathrm{sq}$ feet in 1951, increased in area by only 30 times during the same period. The percentage increase in area is not maintained, therefore, even though the increase in radius of a patch is relatively constant. As new patches develop in an area, fusion of adjacent patches results in a decrease in the number, causing a further decline in the rate of
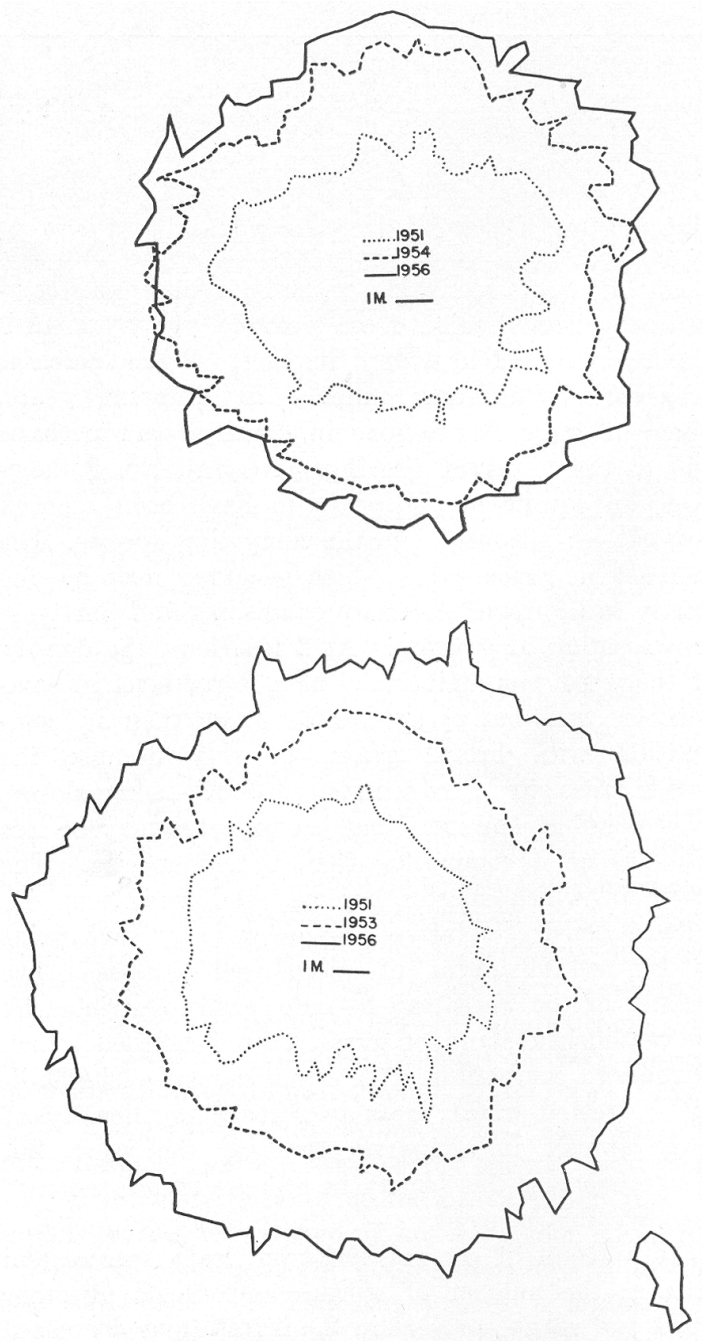

Fig. 8. Diagram showing the increase in area occupied by patches of leafy spurge from 1951 to 1956: A. at Site No. 2; B. at Site No. 3.

radial increase. This decrease was demonstrated along a 0.5 -mile transect (at Site No. 3) (Table 21). Consequently, the rate of increase in the area occupied within a field declines after the initial development. The significance of this principle is indicated by the following calculation. Assuming a lateral spread of 2 feet/year, a patch 0.5 feet in diameter will, in 5 years, increase in area nearly 500 times faster than a patch 25 feet in diameter. A patch 25 feet in diameter has the same surface area as 2,500 patches 0.5 feet in diameter, but if these smaller patches are widely spread, they will in this time attain a total surface area of $825,000 \mathrm{sq}$ feet while the large patch would attain a surface area of only 1,590 sq feet. The significance of the combined effects of migration by seed, spreading of rhizomes by tillage, and lateral development of patches was examined in relation to rate of infestation of larger areas by analysis of data obtained during the Saskatchewan Weed Survey. These surveys show that the capability of spreading, suggested by measurement of patches, is causing rapid increases in acreage over extensive areas of Saskatchewan. 
The degree of association was examined between weather factors and rate of spread of leafy spurge in 4 sites. The weather measurement used was the ratio of total annual precipitation (in inches) to the mean temperature (degrees $\mathrm{F}$ ) for April to September of each year. Correlation coefficients ( $r$ ) between rates of spread and the precipitation-temperature ratio over a 7 -year period ranged from 0.20 to 0.73 , with the highest correlation occurring in the more humid (black soil) sites. Similar calculations on a monthly basis at one site during 1956 (a moist summer) indicated some association between the occurrence of spreading and recession around the periphery of patches with the precipitationtemperature ratio for each month $(\mathrm{r}=$ 0.60). However, in 1957 (a dry summer) there was a negative correlation $(\mathrm{r}=$ -0.73). Lack of correlation was found also with respect to comparison of density of stand and precipitationtemperature ratio. More factors of the environment than current temperature and precipitation are evidently important in controlling vigour of growth of this species.

\section{Effect of flooding}

The distribution of leafy spurge in Saskatchewan has indicated that the weed has a wide ecological amplitude and grows in a wide range of environments, including depressional areas that are periodically flooded. The ability of the plant to withstand flooding was tested by submergence of 4 potted plants for 4.5 months. The shoots survived in 3 pots. All shoots (except one) subsequently died 7 weeks after flooding was discontinued, but new ones emerged from the crowns. In the pot in which the shoots had been killed by flooding, the roots also succumbed. The weed can withstand long periods of flooding in nature, providing the depth of water does not prevent the emergence of shoots above the surface. However, prolonged flooding for 4 years in a depression at one of the study sites caused death of the plants.

Page 36 of 45 


\section{Integration}

Although the vigour of leafy spurge is inherent in the species, the factors of the environment play an important role. The usual sequence of events in relation to habitat can best be illustrated with the discussion of the development of a patch, and their significance, by a review of practical methods of control.

\section{Development of a patch}

The seed of leafy spurge is dispersed in midsummer and autumn and deposited on the surface of the soil. Subsequently the leaves fall and finally the stems. In autumn, seeds may be found lying on the soil surface, but by the following spring they are covered by debris. Several factors in nature appear to reach an optimum simultaneously for germination of the seed. Within 12 months after dehiscence of the seed, it is covered by a layer of debris, which reduces light intensity, retains moisture, and has decomposed sufficiently to provide a suitable substratum for germination at a time when conditions within the seed are most favourable.

Germination in spring follows several days of air temperatures of $26^{\circ}$ to $28^{\circ} \mathrm{C}$. The majority of the seeds germinate in the spring, but some seeds will germinate throughout the growing season. Under favorable conditions, $99 \%$ of the seeds will have germinated within 2 years and the remainder either germinated or deteriorated within 5 years.

Except where underground organs are transplanted (by such means as tillage), a new patch starts from a seed which usually germinates in May or June. A second pair of leaves appears within 7 days of emergence. At this time, small vegetative buds are often already present on the root, and it is during this stage that the young seedling appears to develop the capacity for vegetative reproduction. The shoot continues to produce successive pairs of leaves, and the roots become well established during the remainder of the season. The roots may extend 39 inches deep and 20 inches laterally in the first season (Pavlychenko and Harrington 1938), but no inflorescence is produced. The foliage remains green until the occurrence of the first killing frost which causes the latex to disappear. At the end of the first season of growth, well developed vegetative buds 0.25 to 0.5 inch long occur at or slightly above the surface of the soil.

Seedling densities of $2,800 / \mathrm{sq} \mathrm{m}$ are not uncommon, but competition between plants results in population decreases to $1,000 / \mathrm{sq} \mathrm{m}$ on fine-textured soils or to $500 / \mathrm{sq} \mathrm{m}$ on soils of coarser texture. An unusually dry season accentuates this trend, decreasing seedling densities still further.

Spring growth is initiated during the second year from vegetative buds toward the end of April or early May. Several shoots appear from a rhizome where only one was present the previous year. The density of the patch is rapidly increased by the establishment of shoots from underground parts, but also by seedlings. A patch which consisted of 7 shoots in 1951 increased vegetatively to 872 shoots within 3 years. Seedlings often become established in close proximity to, or even in direct contact with, well established horizontal rhizomes, but the role of the seedling is much more important in the origin of new patches beyond the periphery of established patches. After the density has reached 
more than 100 shoots/sq m, a proportion of the shoots often appear stunted and do not grow taller than 3 inches The number of tiny vegetative buds varies from 4 to 10 on each of these thread-like shoots, which have the appearance of seedlings. They may be distinguished, however, by the adherence to the crown of desiccated stems of the previous season's growth. Approximately $60 \%$ of these small shoots appear to be the result of seedling establishment, with the remainder originating from underground parts.

Shoot development proceeds rapidly in the spring. Most of the shoots are nonflowering in late April and early May. The proportion of flowering shoots increases within the next month, even though the number of non-flowering shoots is also increasing. The total number of flowering and non-flowering shoots may continue to increase until September if moisture conditions are favourable. Where moisture is limiting, the density of flowering and non-flowering shoots usually reaches a maximum between late June and mid-July and decreases until mid-September. Extremely unfavourable conditions inhibit the development of the inflorescence. The maximum lateral extension of the patch usually occurs between late June and mid-July. If the soil is very dry, the perimeter shoots dry up, and in September the top growth of the weed covers less area than it did in July. A patch is characterized by flowering shoots in the centre, vegetative shoots around the perimeter, and underground parts extending beyond the perimeter of the vegetative shoots. Vegetative shoots, however, are usually present also in the centre of the patch.

The perimeter of the patch commonly extends from 2 to 3 feet in all directions in one season, and occasionally as much as 11 feet. A patch (at Site No. 6) which initially consisted of 7 shoots within an area of 2.5 sq feet spread vegetatively to occupy 470 sq feet in 5 years. The size of the patch increased by $300 \%$ the first year and between 17 and $40 \%$ in subsequent years. There is no evidence to indicate that spreading will not continue indefinitely in this manner.

The root system occupies the soil from the surface to great depths. Roots have been traced to a depth of 15 feet (Bakke 1936). Enlargement of the rhizome occurs just below the surface of the soil as a result of annual development of vegetative buds. This enlargement may exceed 1 inch in diameter. The thick, tough stele and the thick, corky bark of the older root portions provide strength and sufficient insulation to maintain normal activities within the root despite unfavourable root-water relationships (Pavlychenko and Harrington 1938). These authors (1938) found no dead or functionless material in root systems of leafy spurge which were 6 years old, and there has been no evidence of deterioration of underground parts in the present study. The enormous reservoir of food located in the phloem, cortex and pith of the root (Bakke 1936) contributes to the survival of the weed during unfavourable conditions.

Vegetative shoots from underground parts generally have initiated an inflorescence within a week after emergence and produced ripe seed after an interval of 6 weeks. The inflorescence develops in successive waves, so that flowering and seed production may occur continuously from early May to late August. The capsules dehisce on warm, sunny days catapulting the seeds to distances of 15 feet (Bakke 1936). Many fall within the patch, others beyond it. If moisture is abundant, lateral branches in close proximity to the terminal umbel continue to develop inflorescences from late August until freeze-up. Successive development occurs on lateral branches from apex to base. After the terminal inflorescence has completed its flowering cycle, the bracts fall to the ground and the shoot 
dies at the tip, so that it resembles a living tree with a dead crown. The bracts provide the greenish-yellow colour of the inflorescence which is characteristic in spring and summer. As the season progresses, the initial greenish hues change to gold, and in autumn, become yellowish-orange. During the same interval, the stems change from a rich green to an orange shade of red. Shoots shorter than 3 inches similarly develop the autumnal hues. The dead culms of the previous season's growth persist for as long as 2 years. With the deterioration of stems in autumn, there is further development of buds located just above or at the soil surface. These buds may reach 0.75 inch in length at this time, but remain dormant to elongate and produce shoots the following spring.

Intense competition from grass species may decrease the number of shoots and inhibit development of the inflorescence. Herbaceous vegetation, however, has not been successful in preventing horizontal extension of the roots. A tall, dense stand of woody plants (e.g. aspen) may limit lateral extension of leafy spurge and, where the light is severely limiting, may prevent its establishment.

Leafy spurge is capable of tolerating a remarkable degree of disturbance. The removal of top growth by 2,4-Dichlorophenoxy-acetic acid or tillage, results in increased densities of the weed, sometimes by as much as $100 \%$. The removal of the surface 1 foot of roots and rhizomes does not significantly affect density or vigour of the species, while the removal of 2 feet of underground parts results in decreased densities of topgrowth. The species can occasionally recover from the removal of the surface 3 feet of underground parts.

Leafy spurge possesses a broad ecological amplitude, being represented on several continents in habitats which range from xeric to sub-humid and from sub-tropical to subarctic. The weed appears to be a serious problem only in the continental climate of North America. The problem appears less severe in coastal Atlantic climates or the deciduous forest area of North America. Occasionally in Wisconsin, a patch is overcome and eradicated by invading grasses (J.T. Curtis, personal communication, 1955). Little evidence of invasion of patches into cultivated fields from field margins in Wisconsin was observed during the present study. This may be due to the nature of the crop rotation which is practiced. Possibly a rotation which alternates between legume crops and inter-row cultivation of corn is a combination too rigorous for the weed to endure. The weed is capable of maintaining itself, however, in open stands of oak woods nearby. It is in the prairie climates that leafy spurge exhibits maximum vigour, to the extent of invading and competing vigorously in ungrazed, native grassland.

\section{Control}

Because of the vigour and the tenacity demonstrated by leafy spurge in Saskatchewan, preventive methods which guard against infestation must be considered, as well as eradication in areas which are already infested. Eradication of small patches is possible, but in large infestations the only practical program is to try to achieve control. In all methods applied, whether for the purpose of eradication or control, storage of food in underground parts must be prevented and the development of new patches from seed avoided. 
Since germination takes place mostly within a few weeks in spring concentration of effort at this time, either by tillage or with chemicals, will kill the majority of the seedlings before they reproduce vegetatively. Seedlings 10 days old or less may be killed with 2,4-D at $12 \mathrm{oz} /$ acre (Selleck 1958). Continued vigilance is required, however, since it has been shown that a few seeds will germinate throughout the entire growing season from depths of 0.5 to 2 inches. Extended dormancy of seed adds to the problem of control. Germination was recorded in the field up to 5 years after seeding and occasionally occurred from depths of 6 inches This suggests that eradication can be expected if established plants are killed and seedlings are destroyed each year for 5 years.

Vegetative buds which develop on the underground parts of leafy spurge indicate the stage at which the seedling is capable of vegetative reproduction. Buds become evident on underground parts of seedlings 7 to 10 days after the emergence of the shoot. Regrowth may occur from buds on $50 \%$ of the seedlings at this stage, even when the stems are severed 0.5 inch below the soil surface. Therefore, if a control method is to be successful in eliminating seedlings in one operation, it must executed soon after emergence.

In Saskatchewan, borate compounds have been most effective for control since proper rates of application result in eradication of the spurge, at the same time permitting vigorous competition from competing grasses (Selleck 1959). However, redevelopment of patches from seed after previous infestations have been removed by soil sterilants is a common occurrence. Regardless of the soil sterilant which is used (e.g. sodium chlorate or borate compounds), germination, while initially inhibited, may occur the second year after application due to leaching of the herbicide from the surface layer of soil.

After seedlings are well established, more drastic measures of control are required. The ability to spread vegetatively is acquired so early that soil sterilants should be applied to even very young patches, rather than risk the failure of tillage methods. Since seed is not produced until the second year in the life of a seedling, prompt application of control methods may avoid the possibility of further soil infestation by seed.

Three major factors which have contributed to failures in eradication by soil sterilization in Saskatchewan are: (1) lack of uniform application of herbicide, (2) application over an insufficient area, and (3) failure of follow-up treatment when necessary. The nature of vegetative spread of the weed from underground parts has necessitated application of soil sterilants in a belt extending 6 to 8 feet beyond the most outlying shoots. With the application of spray, there is a natural tendency to apply liberally on the patch, but somewhat meagerly around the perimeter. Thus vigorous vegetative regrowth results along the edge of otherwise dead patches. The necessity of high volume application under high pressure requires the application of spray with a single nozzle. This mechanical limitation makes uniform application virtually impossible, particularly in porous soil, so that "misses" can scarcely be avoided. Granular herbicides are more adaptable to uniform rates of application with the use of metering devices, such as fertilizer spreaders or grass seeders.

Among the soil sterilants which have been used with some success on small patches are diesel fuel, waste transmission and crankcase oil. The same precautions must be taken in their application. 
Success has been attained in control by preventing growth through utilizing infested areas as pig or chicken runs. Several years of rooting or trampling may result in eradication. The same principle has been applied by placing a block of stock salt in the centre of a small patch in a pasture, thus subjecting it to trampling by cattle and horses. After several years, complete eradication may be achieved in these ways.

The results of "burial" and "excavation" experiments suggest that extremely deep cultivation has little merit in control programs. Repeated hoeing of small patches every time growth appears, however, is an effective method in eradication of established patches of the weed. Observations indicate that if it is not permitted to develop beyond a height of about 2 inches throughout the control period, the food supply in the roots will be exhausted within 3 years, resulting in eradication. Such intensive cultivation is often impractical in large infestations, especially on sandy soils, because of the hazard of soil erosion. Where patches are small, intensive cultivation is possible with less risk. To avoid the necessity of continuous intensive tillage, some farmers have alternated this treatment with cropping (every other year) over a period of several years. This method has not resulted in eradication, but has reduced the density of the weed. Application of 2,4-D in the crop year further reduces the weed's vigour, but does not effect elimination. Most successful reports of control by this method have been from areas of heavy clay soil, in which the weed was rooted to a relatively shallow depth.

The ability of crested wheat grass to become established and thrive in competition with leafy spurge, together with its capacity to decrease the rate of vegetative spread, to limit density, to reduce seed production and to suppress top growth of leafy spurge, recommends it highly for control of this weed in Saskatchewan. If 2,4-D is applied to such stands twice a year, seed production will be prevented and the hay may be safely removed for feed. Several applications of 2,4-D at the $2 \mathrm{lb} /$ acre rate (as many as 5 annually) as regrowth warrants, reduces the density of vegetative growth by 95 to $98 \%$ and, if continued for 2 or 3 years, results in eradication (Selleck 1959).

\section{Summary}

Leafy spurge (Euphorbia esula L.) has steadily increased in Saskatchewan since it was first collected in the early 1900s. An investigation was initiated in 1949 with a survey of the distribution of the weed, during which nearly 10,000 acres were found to be infested with leafy spurge in approximately $1 / 3$ of the settled area of Saskatchewan. Life history studies, which were conducted at the same time, were concerned with various details of developmental history and ecological relations, knowledge of which was expected to aid in efforts to control the weed. Several enclosures were established, to permit study in natural infestations under various climatic and soil conditions in several habitats, supplemented by experiments in field plots, greenhouse and laboratory.

The change in area occupied by leafy spurge was determined by plot-mapping and transects and forb and shrub density by counting shoots in sq m quadrats. Grass density was studied by sampling 200 points within each quadrat. 
Phenology of the species was ascertained by observations in field infestations, supplemented by study in the greenhouse and in field plots. Germination studies were conducted in field plots and in petri plates containing vermiculite in the laboratory.

The weed is a perennial forb which spreads both vegetatively and by seed. The seed has spread in Saskatchewan by several agencies, e.g. flowing water and wild and domesticated animals. New infestations have originated also as a contaminant in grass seed and grain and through transport of seed and underground parts by machinery.

Maximum germination of the seed occurs after it has reached an age of 1 year. In the field $99 \%$ of the germination occurs in the first 2 years, although in the laboratory, viability is retained for at least 13 years. There is considerable variation in germination of seed collected from various locations. Fine-textured soils appear to be more conducive to germination and to the establishment of seedlings than coarse-textured soils. Seedlings do not emerge readily from depths greater than 2 inches in the soil.

Seed dormancy can be broken by temperatures of $20^{\circ} \mathrm{C}$ alternating with $30^{\circ} \mathrm{C}$, or by prolonged exposure at $30^{\circ}$ to $32^{\circ} \mathrm{C}$. Alternate freezing and thawing and prolonged dark periods also promote germination. Maximum germination of the seed occurs in May, although some germination continues throughout the season. Brown mottled seeds are more mature, larger, and heavier than grey seeds. Mottled seeds germinate more completely, but imbibe less water. Germination does not necessarily occur after imbibition.

Leafy spurge is a problem as a weed largely because of its capacity for vegetative reproduction. After emergence for 7 to 10 days, the seedlings are capable of vegetative reproduction. The seedling continues to develop throughout the season, but an inflorescence is not produced during the first year. Plants which originate from roots and rhizomes begin growth in Saskatchewan in late April and usually flower by May 10. As the patches develop, density reaches more than 200 shoots/sq $\mathrm{m}$ in sandy soils and as many as $1,000 / \mathrm{sq} \mathrm{m}$ in heavy clay soil. Density usually reaches a maximum into June or July, but under favourable moisture conditions is sustained until late August. Patches of leafy spurge usually spread vegetatively from 1 to 3 feet/year. Although vegetative spread sometimes occurs throughout the season, maximum spread usually occurs in June. Under dry conditions in autumn, the perimeter shoots often die.

Portions of the root system, remaining after the upper 3 feet of the underground parts had been removed, emerged through 3 feet of tamped soil within a period of 12 months. Similar penetration occurred when undisturbed plants were buried under 3 feet of tamped soil.

The species appears to be more vigorous on coarse-textured soils than fine-textured soils as, demonstrated by more rapid vegetative reproduction, deeper root penetration and greater tenacity in withstanding control treatments. Control can be accomplished by tillage or competition from vigorous species of perennial grass, such as Agropyron cristatum. Eradication can be accomplished through the use of soil sterilants, prolonged trampling by animals, or repeated, timely applications of 2,4-D in infestations competing with a vigorous, perennial grass. 
This 10-year study has revealed some of the characteristics accounting for the vigour and tenacity of the weed and suggests refinements in timing and procedure that are important to the success of a control program.

\section{Acknowledgments}

Appreciation is expressed to the following: Dr. J.T. Curtis of the University of Wisconsin for helpful criticism; Drs. J.F. Alex and T.S. Rakshi, whose published works on certain phases of this project have facilitated the interpretation of results of the studies reported below; and Mr. A.R. Brooks of the Canada Agricultural Research Station at Saskatoon for identification of insects. The project was financed by Extramural Research Grants from the Canada Department of Agriculture and by the Saskatchewan Agricultural Research Foundation.

\section{Literature cited}

Anonymous. 1938. Leafy spurge fights back. Expt. Farm News. Publ. and Ext. Div., Dom. Dept. of Agr., Ottawa.

Arny, A. C. 1932. Variations in the organic reserves in underground parts of five perennial weeds from late April to November. Univ. of Minn. Agr. Expt. Sta. Bull. 84:3-26.

Ashbrook, F. G. Birds of America. Whitman Publ. Co., Racine, Wis. p. 46.

Bakke, A. L. 1936. Leafy spurge, Euphorbia esula L. Iowa Agr. Expt. Sta. Res. Bull. 198:209-245.

Bakshi, T. S. and R. T. Coupland. 1959. An anatomical study of the subterranean organs of Euphorbia esula in relation to its control. Can. J. Bot. 37:613-620.

Batho, G. 1931. Leafy spurge. Man. Dept. Agr. and Immigr. Circ. 106.

Batho, G. 1932. Leafy spurge. Man. Dept. Agr. and Immigr. Circ. 106. 2nd ed.

Barnett, H. L. and H. C. Hanson. 1934. Control of leafy spurge and review of literature on chemical weed control. N. D. Agr. Exp. Sta. Bull. 277:1-31.

Bellue, M. K. 1946. Leafy spurge weed seed handbook, Series 5. Calif. Dept. Agr. Bull. 35-36:87-88.

Bellue, M. K. and C. E. Berry. 1941. Additional sites for leafy spurge, Euphorbia esula L. Calif. Dept. Agr. Bull. 30:286-290.

Bentham, G. and J. D. Hooker. 1883. Genera Plantarum III. L. Reeve and Co.: London. p. 261.

Brown, E. O. and R. H. Porter. 1942. The viability and germination of seeds of Convolvulus arvensis L. and other perennial weeds. Iowa Agr. Expt. Sta. Res. Bull. 294:495-504.

Clapham, A. R., Tutin, T. G. and E. P. Warburg. 1952. Flora of the British Isles. Cambridge Univ. Press: London. pp. 688-689.

Clute, W. N. 1933. The meaning of plant names. The spurges. Am. Bot. 39:106-113.

Clute, W. N. 1937. Another plant pest Am. Bot. 43:26-27.

Cosson, E. et G. de Saint-Pierre. 1861. Flore des environ de Paris. Masson et Fils: Paris. pp. 600-601.

Coupland, R. T. 1950. Ecology of mixed prairie in Canada. Ecol. Monog. 20:271-315.

Coupland, R. T. and J. F. Alex. 1954. Distribution of the underground parts of leafy spurge (Euphorbia esula L.). Can. J. Agr. Sci. 34:161-176. 
Coupland, R. T. and J. F. Alex. 1955. Distribution of vegetative buds on the underground parts of leafy spurge (Euphorbia esula L.). Can. J. Agr. Sci. 35:76-82.

Coupland, R. T., Selleck, G. W. and J. F. Alex. 1955. The reproductive capacity of vegetative buds on the underground parts of leafy spurge (Euphorbia esula L.). Can. J. Agr. Sci. 35:477-484.

Coupland, R. T. and T. C. Brayshaw. 1953. The fescue grassland in Saskatchewan. Ecology. 34:386-405.

Craig, H. A. 1953. Committee reports of the Western Section, National Weed Committee. p. 3.

Croizat, L. 1945. "Euphorbia esula" in North America. Am. Midl. Nat. 33:231-244.

Cummings, K. 1941. Early development of the latex system in Euphorbia species. Abstract. Am. J. Bot. 28:728.

De Lamarck, J. B. and A. P. De Candolle. 1806. Synopsis Plantarum in Flora Gallica Descriptarum. Apud H. Agasse: Paris. p. 187.

Drude, O. 1896. Deutschlands Pflanzengeographie. Erster Teil. J. Engelhorn: Stuttgart. pp. 204-206.

Fernald, M. L. 1950. Gray's Manual of Botany. 8th ed. American Book Co.: New York.

Fix, E. E. 1946. Leafy spurge (Euphorbia esula L.). Calif. Dept. Agr. Bull. 35:122-123.

Gaucher, L. 1902. Recherches anatomiques sur les Euphorbiacees. Ann. d. Sci. Nat. 15:161-309.

Groh, H. 1935. Leafy spurge-Euphorbia esula or virgata? Sci. Agr. 15:701-703.

Groh, H. 1944. Euphorbia esula L. Canadian Weed Survey, First Report. Dept. Agr., Sci. Serv., Ottawa. pp. 19-20.

Groh, H. and C. Frankton. 1949. Canadian Weed Survey, Seventh Report. Dept. Agr., Sci. Serv., Ottawa. pp. 34-35.

Haberlandt, G. 1914. Physiological plant anatomy. Macmillan and Co. of Canada Ltd.: Toronto. pp. 305, 337-345.

Hanson, H. C. 1933. Distribution of leafy spurge (Euphorbia virgata) in the United States. Sci. 78:35.

Hanson, H. C. and V. E. Rudd. 1933. Leafy spurge, life history and habits. N. D. Agr. Coll. Bull. 266:1-24.

Hegi, G. C. 1906. Illustrierte Flom von Mittel Europa mit besonderer Berucksichtigung von Deutschland, Oesterreich und der Schweiz. F. P. Datterer and Cie: Freising-Munchen. Band V, T. 1:170-172.

Heimans, E., Heinsius, H. W. and J. P. Thijsse. 1948. Geillustreerde Flora von Nederland. W. Versulys (N. V.): Amsterdam. p. 604.

Helgeson., E. A. and H. C. Hanson. 1938. Leafy spurge. N. D. Expt. Sta. Circ. 55. 4 pp.

Kendrew, W. G. and B. W. Currie. 1955. The climate of central Canada. Queen's Printer: Ottawa. 194 pp.

Kirk, L. E., Pavlychenko, T. K. and D. W. Staniforth. 1940. Eradication of perennial weeds. Rept. Investig. Res. Lab. Plant Ecology, Univ. of Sask., Saskatoon. Unpubl. pp. 12-16.

Knuth, P. 1909. Handbook of flower pollination. Trans. by J. R. Davis. Clarendon Press: Oxford. pp. 365-368.

Kummer, A. P. 1951. Weed seedlings. Univ. of Chicago Press. p. 163.

Kupsch, W. O. 1960. Radiocarbon dated organic sediment near Herbert, Saskatchewan. Amer. J. Sci. In press.

Landes, M. 1946. Seed development in Acalypha rhomboidea and some other Euphorbiaceae. Am. J. Bot. 33:562-568.

Lindsay, D. R. 1950. Biology of leafy and cypress spurge with notes on their distribution in Eastern Canada. Proc. Fourth Meeting, Eastern Section, Nat. Weed Committee, Ottawa. pp. 68-71.

Linné, C. 1753. Species Plantarum. T. I. Holmiae impensis Laurentii Salvii. p. 461.

Litzenberger, S. C., Post, A. H. and H. E. Morris. 1945. Important perennial weeds in Montana, their identification and control. Mont. Expt. Sta. Bull. 426:43 pp.

Page 44 of 45 
Maguire, B. 1941. Weed records for the Great Basin. Torreya 41:164-166.

Mitchell, J., Moss, H. C. and J. S. Clayton. 1944. Soil survey of southern Saskatchewan, Report No. 12. Univ. of Sask., Saskatoon.

Mitchell, J. and H. C. Mooand 1948. The soils of the Canadian section of the Great Plains. Soil Sci. Soc. Am. Proc. 13:1431-1437.

Monson, W. G., Haskins, F. A. and N. E. Shafer. 1957. Phenological studies of bud dormancy in two deeprooted perennial weeds. Res. Rept. NCWCC: pp. 166-167.

Moore, R. J. 1958. Cytotaxonomny of Euphorbia esula in Canada and its hybrid with Euphorbia cyparissias. Can. J. Bot. 36:547-559.

Muenscher, W. C. 1940. Poisonous plants of the United States. Macmillan Co.: New York. pp. 142-144.

Murley, R. M. 1945. Distribution of Euphorbiaceae in Iowa with seed keys. Iowa State Coll. J. Sci. 19:415-428.

Norton, J. S. B. 1899. A revision of the American species of Euphorbia of the section Tithymalus occurring north of Mexico. Missouri Bot. Garden, 11th rept. pp. 85-147.

Pavlychenko, T. K. 1942. The place of crested wheatgrass (Agropyron cristatum L.) in controlling perennial weeds. Sci. Agr. 22:459-463.

Pavlychenko, T. K. and J. B. Harrington. 1938. Root systems of single plants of leafy spurge (Euphorbia esula L.). Rept. Investig. Research Lab. Plant Ecology, Univ. of Sask., Saskatoon. Unpubl. pp. 12-27.

Pax, F. 1897. Euphorbiaceae. In Engler A. and K. Prantl. 1897. Die naturlichen pflanzen familien. III. Leipzig. p. 109.

Ridley, H. N. 1930. The dispersals of plants throughout the world. L. Reeve and Co.: Ashford, Kent. pp. 520-527.

Rydberg, P. A. 1932. Flora of the prairies and plains of Central North America. New York Bot. Garden. pp. $455,796$.

Selleck, G. W. 1958. Life history of leafy spurge. Proc. NSWCC: Cincinnati, Ohio. pp. 16-17.

Selleck, G. W. 1958. The effect of 2,4-D and borate compounds on regrowth of leafy spurge and toadflax. Proc. NCWCC: Cincinnati, Ohio. p. 87.

Selleck, G. W. 1959. 1) Leafy spurge control with 2,4-D 2) Granular herbicides on leafy spurge and toadflax. Proc. NCWCC: Winnipeg, Manitoba. p. 70.

Sendtner, O. 1860. Die Vegetations-Verhaltnisse des Bayerischen Waldes nach den Grundsatzen der Pflanzengeographie. Nachdem manuscripte des Verfasser volleiidet von Munchen. p. 326.

Sterling, G. R. 1956. The control of leafy spurge in Alberta. Alta. Dept. Agr. 4 pp.

Stevens, O. A. 1932. The number and weight of seeds produced by weeds. Am. J. Bot. 19:784-788.

Stevens, O.A. and L. F. Rock. 1952. Outline for ecological life history studies of herbaceous plants. Ecology. 33:415-422.

Von Kirchner, O. and E. Loew. 1930. Lebensgechichte der Blütenpflantzen Mitteleuropas. Stuttgart. pp. 268-270, 298-300.

Warren, R. and V. Freed. 1953. Leafy spurge. Oregon State Agr. Ext. Bull. 735. 3 pp.

White, A., Dyer, R. A. and B. L. Sloane. 1941. The succulent Euphorbieae (Southern Africa). Abbey Garden Press: Pasadena, Calif. Vol. 1 and 2. 1084 pp.

Wicks, G. A. and L. A. Derscheid. 1958. Leafy spurge seed maturation studies. Proc. NCWCC: Cincinnati, Ohio. pp. 17-18. 